\title{
Mortuary Caves and the Dammar Trade in the Towuti-Routa Region, Sulawesi, in an Island Southeast Asian Context
}

\author{
DAVID BULBECK, FADHILA ARIFIN AZIZ, SUE O'CONNOR, \\ AMBRA CALO, JACK N. FENNER, BEN MARWICK, JIM FEATHERS, \\ RACHEL WOOD, AND DYAH PRASTININGTYAS
}

\section{INTRODUCTION}

THIS ARTIClE DESCRIBES THE SEQUENCE OF MORTUARY PRACTICES and associated funerary items in the Towuti-Routa region of Sulawesi during the first and second millennia A.D. in the context of the broad chronology of similar customs documented elsewhere across Island Southeast Asia (ISEA). In particular, the mortuary sequence in Towuti-Routa is compared with sequences spanning the centuries A.D. in Old Luwu to the immediate west. Trade in dammar gum, which was used to coat mortuary vessels, was an economic mainstay in Old Luwu and Towuti-Routa at the time of European contact. Dammar gum is investigated for its potential role in financing the import of exotic goods, underpinning regional networks that facilitated the spread of mortuary traditions, and promoting the development of a chiefly social organization.

Towuti-Routa includes the land bordering Lake Towuti in South Sulawesi Province and the Routa regency including the Walandawe district in Southeast Sulawesi Province (Fig. 1). The two dominant geological formations in the area are a sinusoidal member of Cretaceous ultramafics and a calcilutite limestone member that includes steep karsts. Lake Towuti is Sulawesi's largest lake and the most ecologically diverse of the Malili system lakes, which extend north to Lake Matano. The southern watershed

\footnotetext{
David Bulbeck is a Visiting Fellow in the Department of Archaeology and Natural History, the Australian National University. Fadhila Arifin Aziz is a Research Fellow in the Department of Prehistory, National Research Center of Archaeology, Jakarta, Indonesia. Sue O'Connor is Distinguished Professor in the Department of Archaeology and Natural History, the Australian National University. Ambra Calo is a Discovery Early Career Researcher in the Department of Archaeology and Natural History, the Australian National University. Jack N. Fenner is a Research Fellow in the Department of Archaeology and Natural History, the Australian National University. Ben Marwick is a Senior Research Fellow in the Centre for Archaeological Science, University of Wollongong, Australia and an Associate Professor in Anthropology Department at the University of Washington, Seattle. Jim Feathers is Director of the Luminescence Dating Laboratory, University of Washington, Seattle. Rachel Wood is a Discovery Early Career Researcher at the Radiocarbon Facility, Research School of Earth Sciences, the Australian National University. Dyah Prastiningtyas is a Research Associate at the Center for Prehistory and Austronesian Studies, Jakarta, Indonesia.
} 


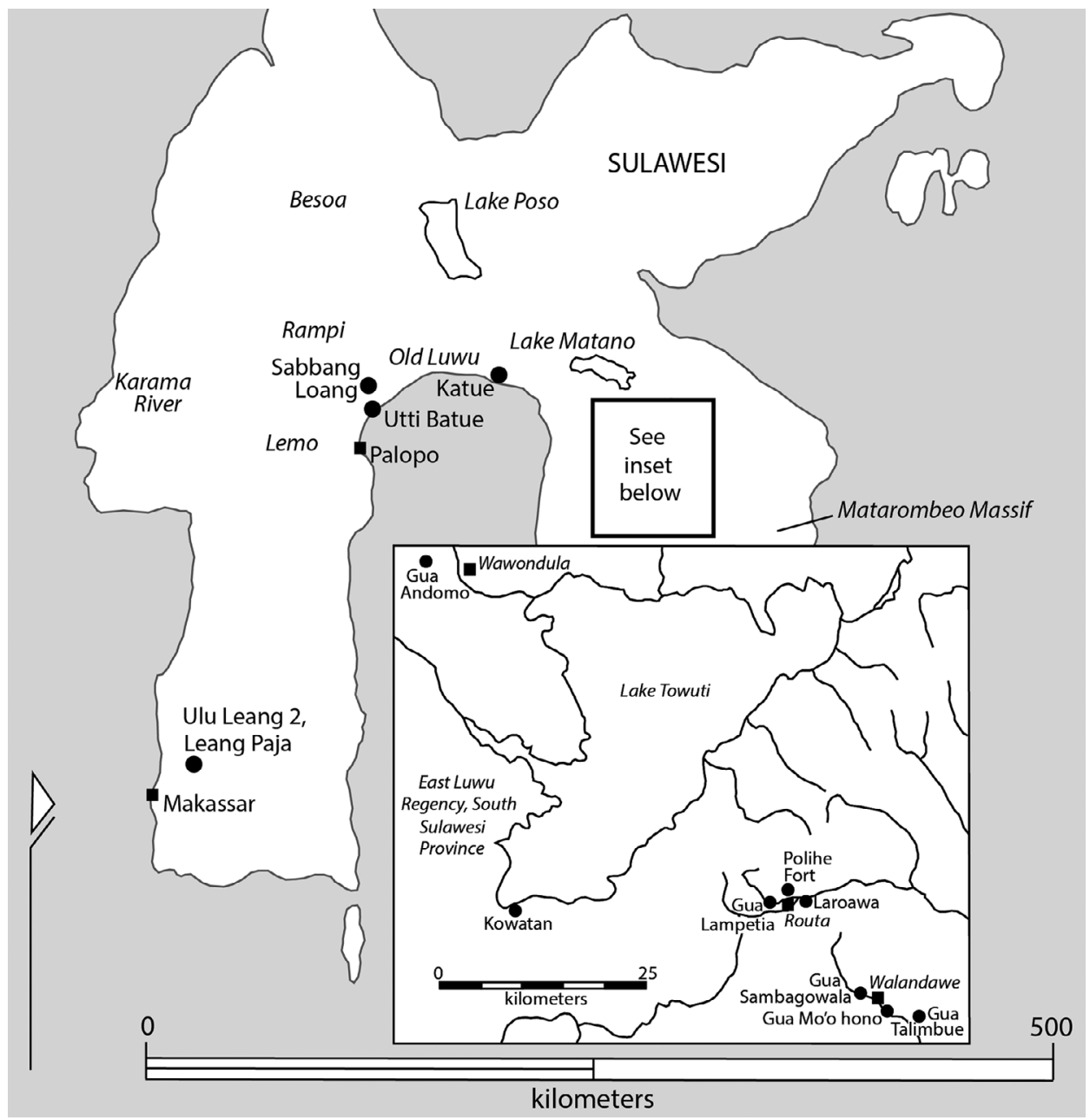

Fig. 1. Central Sulawesi and Western Sulawesi sites and other places mentioned in the text.

of the Malili system lies about $20 \mathrm{~km}$ south of Lake Towuti. The dissected terrain south of the watershed is drained by southward-trending rivers, including the Waki and the Wiwirano. Land cleared for settlement and gardens flanking the waterways give way to forest cover on the slopes and ridges. The fertility of the soils is generally poor, especially at the ultramafic outcrops, but the warm temperatures and abundant year-round rainfall sustain diverse forests that include dammar-yielding dipterocarps (O'Connor et al. 2014).

Towuti-Routa is the focus of an archaeological project titled "The Archaeology of Sulawesi: A Strategic Island for Understanding Modern Human Colonization and Interactions Across our Region." ${ }^{1}$ The two periods covered by datable archaeological traces at Towuti-Routa are the pre-pottery (pre-Neolithic) period from the terminal Pleistocene to about 1500 B.C. (Aplin et al. 2016) and the Palaeometallic to historical period, represented by mortuary and habitation remains dating to the centuries A.D. 
Findings from the latter period can be compared with those examined for the "Origins of Complex Society in South Sulawesi" (OXIS) project, which investigated the evolving iron industry during Palaeometallic and historical times in Old Luwu between Lake Matano and the historical city of Palopo (Bulbeck and Caldwell 2000). ${ }^{2}$ The ethnohistorically spoken languages of the general region represent two "stocks" within the Malayo-Polynesian branch of Austronesian. The three main divisions of the Bungku-Tolaki stock overlap at Towuti-Routa, including Bungku dialects to the east, Tolaki dialects to the south, and Padoe, a Mori language, to the west (Mead 1999). Mori dialects are also spoken in the northern reaches of Old Luwu, whereas the Luwuq, Lemolang, and Bugis languages to the southwest belong to the South Sulawesi stock (Friberg and Laskowske 1989).

Like other islands of the eastern archipelago, Sulawesi was largely unaffected by Hindu-Buddhism and was visited by Europeans before Islam had made a large-scale impact on local beliefs. As described in a variety of sixteenth- to twentieth-century European sources, there was widespread belief that spirits of people's ancestors dwelling in a nonmaterial realm continued to nurture their living descendants. Guided by community protocols, deceased community members received mortuary treatment suitable to prepare them for their appropriate station in the afterlife and support their capacity to wield influence in the realm of the ancestors. This general perspective on indigenous Malayo-Polynesian "ancestor worship" has been employed for interpreting a range of mortuary assemblages, including those thought to have a direct historical relationship with the assemblages of societies recorded by early European visitors (Bougas 2007; Harrisson 1990; Junker 2001) and those whose association with ethnographically recorded groups is unclear (Bulbeck 2001; Tillotson 1989).

Archaeologists studying Neolithic (associated with pottery but no metals) and Palaeometallic mortuary assemblages dating between c. 3500 and 1000 years ago in ISEA, have generally sought evidence for cultural interconnections based either on mortuary practice details or associated material culture such as pottery decorations. The geographic scope of the posited interconnections can be local, as with the investigations in highland Sumatra (Bonatz 2012), or regional, such as Bellwood's (1988) comparison of mortuary remains from Sabah, the central Philippines, and the Sangihe Sea. Some comparisons have ventured farther across ISEA to adjacent southern coastal Vietnam, where Malayo-Polynesian (Chamic) languages are also spoken. Examples include Solheim's (1964) recognition of a Sa Huynh-Kalanay tradition of decorated mortuary pottery and Bellwood's (1997) proposal that the use of earthenware jars as mortuary containers ("jar burials") was a tradition independently developed and maintained by Malayo-Polynesian speakers.

Our study of the Towuti-Routa mortuary archaeology follows a different approach by emphasizing the primacy of local factors rather than the role of external influences. For instance, we note an inverse relationship between whether a mortuary practice is documented widely across Towuti-Routa and whether it can be plausibly linked to external influence (Table 1). We further propose that the uptake of a mortuary practice reflects its suitability as a localized material expression of ancestor worship in the context of local communities' technological skills and access to exotic goods. Finally, our investigations register an early (Palaeometallic) exploitation of the region's abundant dammar resources, but suggest that the development of a systematic dammar trade was essentially confined to the historical period. 
Table i. Summary of Three Mortuary Practices Documented for Towuti-Routa

\begin{tabular}{|c|c|c|c|}
\hline PRACTICE & $\begin{array}{l}\text { DOCUMENTED } \\
\text { DURATION AND } \\
\text { EXTENT }\end{array}$ & GEOGRAPHICALLY CLOSEST MATCH & $\begin{array}{c}\text { PLAUSIBLE EXTERNAL } \\
\text { INFLUENCE }\end{array}$ \\
\hline $\begin{array}{l}\text { Secondary disposal } \\
\text { of remains of } \\
\text { deceased on cave } \\
\text { floors, including } \\
\text { aristocrats in large } \\
\text { imported jars }\end{array}$ & $\begin{array}{l}\text { c. A.D. } 1500- \\
\text { 1900, across } \\
\text { Towuti-Routa }\end{array}$ & $\begin{array}{l}\text { Large mortuary jars (earthenware, } \\
\text { undated) on the Rukuo and } \\
\text { Anawai cave surfaces, } \\
\text { Matarombeo Massif, Southeast } \\
\text { Sulawesi (Fage 2014) }\end{array}$ & $\begin{array}{l}\text { None found (the } \\
\text { Rukuo/Anawai } \\
\text { jars and Towuti- } \\
\text { Routa remains } \\
\text { could represent } \\
\text { the same tradition) }\end{array}$ \\
\hline $\begin{array}{l}\text { Secondary burial of } \\
\text { multiple persons in } \\
\text { large earthenware } \\
\text { jar }\end{array}$ & $\begin{array}{l}\text { c. A.D. } 1000 \text {, at a } \\
\text { single site }\end{array}$ & $\begin{array}{l}\text { Large earthenware burial jars } \\
\text { (contents not preserved) dating } \\
\text { to first millennium A.D. at } \\
\text { Sabbang Loang, Old Luwu }\end{array}$ & Old Luwu \\
\hline Extended inhumation & $\begin{array}{l}\text { c. A.D. } 300-1100 \text {, } \\
\text { at } 3 \text { Towuti- } \\
\text { Routa sites }\end{array}$ & $\begin{array}{l}\text { Fourteenth-seventeenth century } \\
\text { A.D. burial tradition of Makassar } \\
\text { speakers, southwest Sulawesi }\end{array}$ & None clear \\
\hline
\end{tabular}

\section{ETHNOHISTORY OF THE TOWUTI-ROUTA STUDY REGION}

In 1911, Berlin zoologist Albert Grubauer arrived in Macassar (now Makassar), then the administrative center for the southern half of Sulawesi. He learned that Lake Towuti was the main source of dammar, which was Macassar's major export at the time. He journeyed to Lake Matano and then trekked to the eastern shore of Lake Towuti through lands inhabited by the Leoka (i.e., the Padoe), whom he described as similar to the Toraja "highland people" of central Sulawesi. Approaching southeast Lake Towuti, he encountered a group he called the Tolambatu whose customs reminded him of the "Dayaks" and Dusun of Borneo (Grubauer 1913). At the time, the widespread Bungku language included a Routa dialect near Lake Towuti and a Tolambatu dialect well to the southeast (Mead 1999), so it is likely that Grubauer had confused these two Bungku dialects.

Until shortly before Grubauer's visit, the corpses of the deceased were stored beneath family houses until their bones were defleshed and ready for transport to communal mortuary caves. Commoner and aristocratic adults were accorded different treatment. Commoners were stored in wooden coffins or wrapped in cloth and temporarily buried. Every eight to twelve months, a mortuary feast was held to accompany the collection of the bones and clothing of deceased commoners for transport in wooden caskets to a cave in the mountains. By contrast, deceased aristocrats were stored in finely decorated, wooden litters, along with their personal effects. Every three to five years, their bones were collected for storage in Chinese martavans (stoneware jars). These were placed in the litter along with a life-size wooden image of the deceased. Amidst great fanfare, the litter was carried to a communal mortuary cave. Deceased children, whether commoner or aristocrat, were also taken to a mortuary cave following a mortuary feast held by the immediate family (Grubauer 1913).

The "Tolombatu" (Bungku) at Lake Towuti directed Grubauer to Routa as their ancestral home, but he found the village of Routa virtually deserted when he arrived. He was guided to a disused mortuary cave an hour's trek east of Routa. He recorded 
litters for the nobility and coffins for the commoners in varying states of disrepair depending on how much they had been exposed to the elements. Some attention had been given to keeping the skulls collected together, but the other bones lay strewn across the cave floor, along with wooden bric-a-brac, death hats from wooden images, and the aristocrats' garments, ornaments, weapons, crockery, and victuals for their afterlife (Grubauer 1913).

Social anthropologists McWilliam and Lorenzen (2009) conducted the first survey of the Towuti-Routa mortuary caves. Then, in 2011, a team of Indonesian and Western archaeologists inspected these and other sites for their excavation potential (Bulbeck et al. 2011). Additional mortuary caves were surveyed during the 2012 and 2013 excavation field seasons (O'Connor et al. 2014). As described in this article, we identified two mortuary practices that precede the ethnohistorical tradition described by Grubauer in three of the five excavated limestone caves: Gua Talimbue, Gua Andomo, and Gua Lampetia (Fig. 1; Table 1).

\section{GUA TALIMBUE}

Gua Talimbue lies in Walandawe, the part of the study region traditionally inhabited by Wiwirano (Tolaki) speakers (Mead 1999). It has a large, well-lit entrance and a complex of back chambers with mortuary disposals similar to those described by McWilliam and Lorenzen (2009). Excavations, mainly $\mathrm{m}^{2}$ test pits removed in $5 \mathrm{~cm}$ artificial levels (AL), focused on the west and east parts of the cave entrance (Fig. 2).

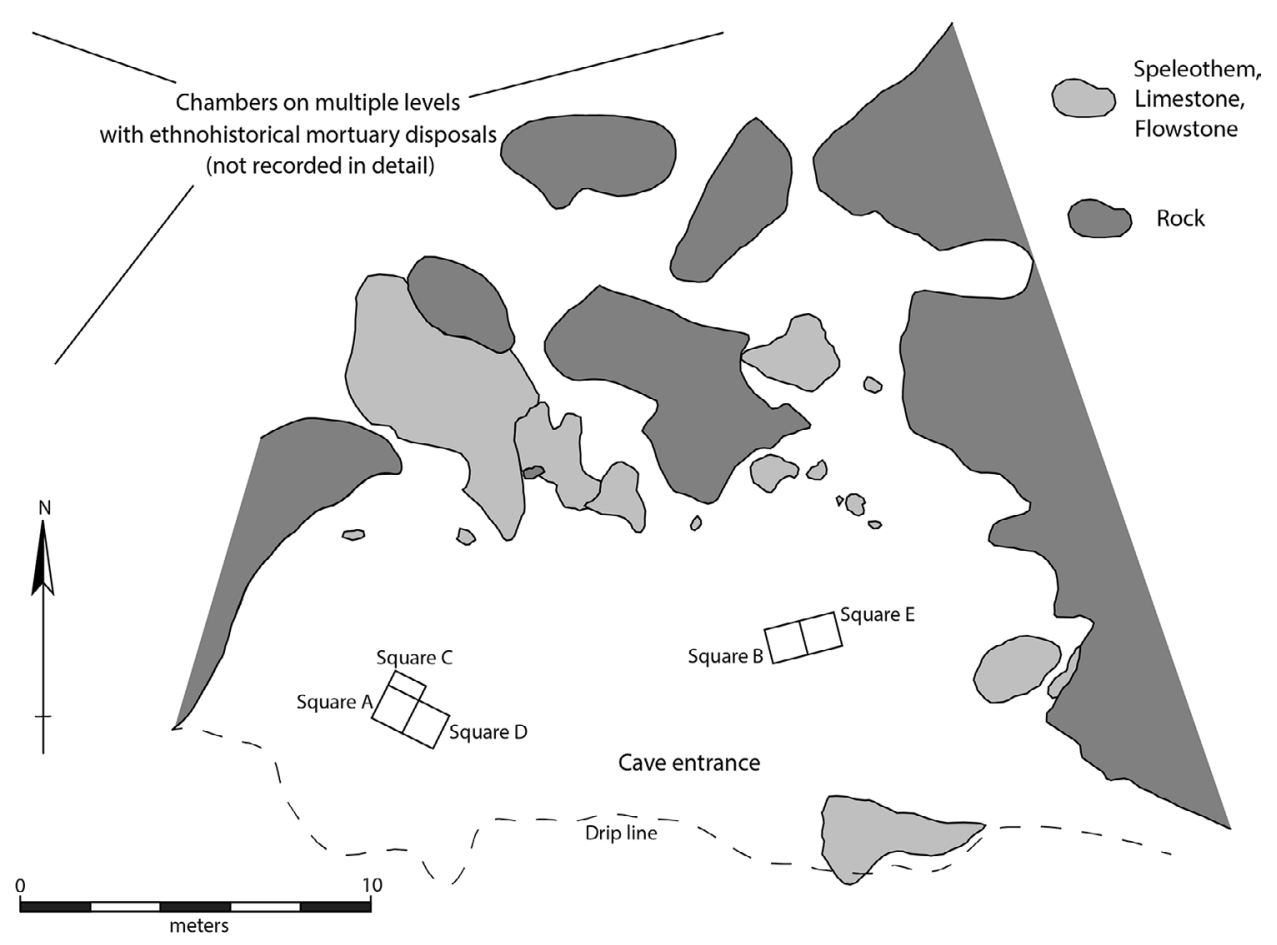

Fig. 2. Gua Talimbue entrance showing location of excavated squares. 
The overall habitation sequence of over $4 \mathrm{~m}$ depth from the terminal Pleistocene to the late Holocene has been dated by a generally consistent series of Accelerator Mass Spectrometry (AMS) dates on charcoal from Square B (Aplin et al. 2016). These have been calibrated against IntCal13 (Reimer et al. 2013) in Oxcal version 4.2 (Bronk Ramsey 2013), as have all of the ${ }^{14} \mathrm{C}$ dates presented in this section.

In Square A, at the west, the extended burial of an elderly female was encountered about $40 \mathrm{~cm}$ below the surface. The individual appears to have survived for at least several years without functioning dentition: the mandible is edentulous with healedover alveoli and the small number of preserved maxillary tooth sites lack any teeth. Poor dental health is associated in pre-industrial times with an agriculturally based diet (Hillson 1996). Square D and the half-square C were then excavated to allow removal of the skeleton (Fig. 3). Glass beads, an iron pendant, and ornate earthenware pottery, found down to AL 11 in squares A, C, and D, appear to be mortuary goods associated with the burial. A sample of bone taken from the skeleton's left femur proved to be of adequate quality for reliable AMS dating and returned a date of about A.D. 250-400 (Tables 2, 3).
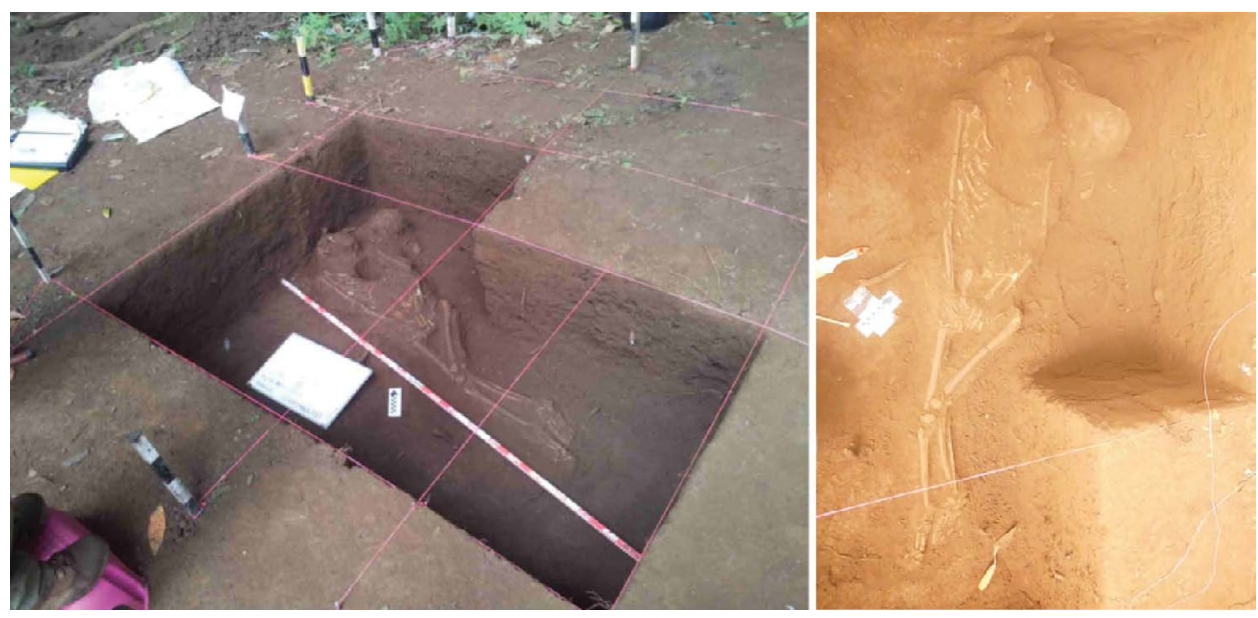

Fig. 3. Extended burial of elderly female at Gua Talimbue.

Table 2. Indicators of the Quality of Bone Collagen* from Gua Talimbue (SANU 404I 8)

\begin{tabular}{ll}
\hline COLLAGEN QUALity ASSURANCE & \multicolumn{1}{c}{ DATA } \\
\hline Collagen yield & 24.0 mg, 4.3 weight $\%$ \\
$\% \mathrm{C}$ & $36.8 \%$ \\
$\mathrm{C}: \mathrm{N}$ & 3.3 \\
$\delta^{13} \mathrm{C}$ & $-20.6 \%$ \\
$\delta^{15} \mathrm{~N}$ & $7.8 \% 0$ \\
\hline
\end{tabular}

* Extracted with an ultrafiltration protocol and AMS dated. For a reliable date, more than 1 weight $\%$ of the bone should be collagen, more than $30 \%$ of the collagen should be carbon, and the collagen should have a $\mathrm{C}: \mathrm{N}$ of $2.9-3.4$. Stable isotopes should be representative of the individual's diet, in this case a terrestrial omnivore (van Klinken 1999). 
Table 3. Gua Talimbue AMS Dates Younger Than 2000 B.C.

\begin{tabular}{|c|c|c|c|c|c|c|}
\hline SQUARE & $\begin{array}{l}\text { ARTIFICIAL } \\
\text { LEVEL }\end{array}$ & $\begin{array}{l}\text { LABORATORY } \\
\text { CODE }\end{array}$ & MATERIAL & $\begin{array}{l}\text { UNCALIBRATED } \\
\text { DATE }\end{array}$ & $\begin{array}{c}\text { CALIBRATED } \\
\text { DATE }(95 \% \\
\text { PROBABILITY } \\
\text { RANGE) }\end{array}$ & ASSOCIATION \\
\hline B & 3 & D-AMS 004027 & Charcoal & $347 \pm 26$ в.Р. & $\begin{array}{c}\text { 1465-1635 } \\
\text { cal A.D. }\end{array}$ & $\begin{array}{c}\text { Lowest Square } \\
\text { B pottery }\end{array}$ \\
\hline A & $8-10$ & SANU 40418 & $\begin{array}{l}\text { Human } \\
\text { bone }\end{array}$ & $1710 \pm 20$ в.Р. & $\begin{array}{c}256-393 \\
\text { cal A.D. }\end{array}$ & Extended burial \\
\hline B & 8 & D-AMS 004028 & Charcoal & $3372 \pm 27$ в.Р. & $\begin{array}{c}\text { 1742-1614 } \\
\text { cal в.с. }\end{array}$ & $\begin{array}{l}\text { Uppermost pre- } \\
\text { pottery date }\end{array}$ \\
\hline
\end{tabular}

Decorated pottery similar to that associated with the burial was recovered at a lower density down to AL 3 in Square B and AL 6 in Square E, at the east of the cave entrance. Two AMS dates are available for the upper eight artificial levels in Square B, a date of about A.D. 1500 from AL 3 and a date of about 1700 B.C. from AL 8 (Table 3). AL 4 to 7 in Square B would presumably cover the c. 1500-1 B.c. interval when there was a transition from plain red-slipped pottery to plain unslipped pottery at the Karama River sites in West Sulawesi (Anggraeni et al. 2015). However, there is no sign of pottery at Gua Talimbue older than the Palaeometallic pottery associated with the extended burial.

\section{GUA ANDOMO}

Gua Andomo, which lies in the part of the study region traditionally inhabited by Padoe speakers (Mead 1999), includes a lower and an upper chamber with mortuary disposals (Fig. 4). A $50 \mathrm{~cm} \times 50 \mathrm{~cm}$ test pit was excavated near the center of the upper chamber in the vicinity of several clusters of wooden coffins containing the secondarily stored bones of sub-adults (teenagers) and adults. The coffins, which are held together with early twentieth-century nails, include rectangular boxes and square containers with centrally peaked covers (Fig. 5). The upper chamber is accessed via a sloping tunnel through the limestone from a cavity at the rear of the lower chamber. The lower chamber is dominated by rock and flowstone, with only a small area of sediment at the entrance, where a second $50 \mathrm{~cm} \times 50 \mathrm{~cm}$ test pit was excavated (Fig. 6). Ethnohistorical mortuary remains include nine adult crania lodged in cavities within a rock warren (a maze of loosely clustered boulders) at the east and rectangular coffins suspended from the walls at the west.

The test pits yielded sherds of local earthenware and imported ceramics, supplemented by beads of glass and other materials, wood, copper-based ornaments, and in Test pit 2 two indecipherable Chinese coins and a variety of iron fragments. The imported ceramics mostly date to between the fifteenth and nineteenth centuries. Sherds from martavans and other large jars date to between the sixteenth and eighteenth/nineteenth centuries (Table 4). Both test pits were taken to bedrock, but there was no sign of increasing age of the contents with depth. For instance, sherds of European bottle glass were found in five of the nine artificial levels in Test pit 2 including the top and bottom levels. The reported looting of the site for antiques may be a contributing factor to this lack of chronological resolution. 


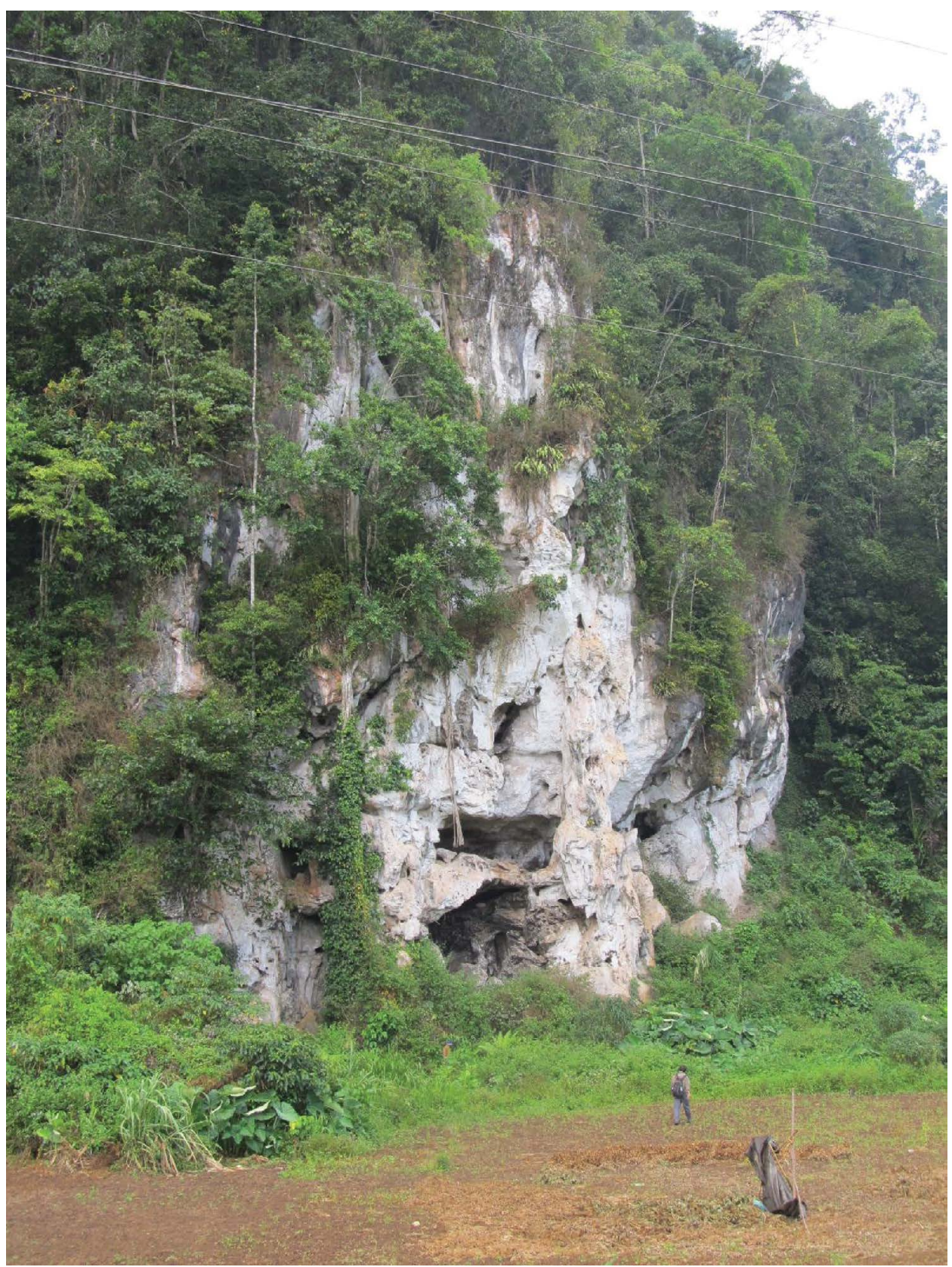

Fig. 4. Gua Andomo lower and upper chambers, from the south.

Both test pits yielded fragmentary human remains, including teeth, manual and pedal extremities, and fragments from the cranium, vertebral column, pelvis, radius, femur, patella, and feet. Analysis of the dental remains demonstrates a minimum number of five children, aged between four years old and adolescence, and four adults of 


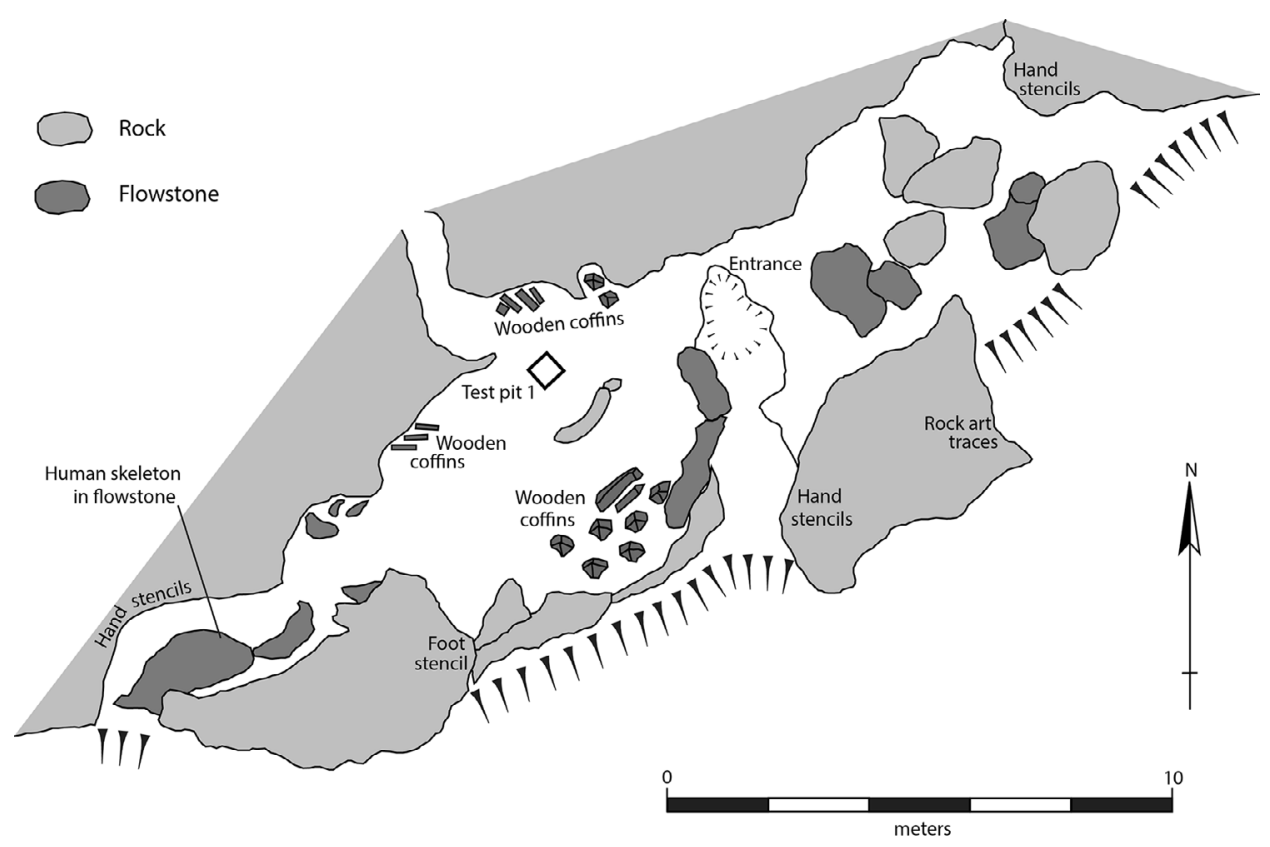

Fig. 5. Gua Andomo upper chamber showing location of Test pit 1.

various ages. One adult is represented by a left maxillary fragment with advanced alveolar recession at its canine and first premolar sites, a second adult by well-worn teeth including a third molar with a carious pit, and the other two adults by assortments of teeth with betel-nut staining. Thus, the dental remains evidently reflect a substantial agricultural component in the diet.

The upper chamber also includes a semicomplete skeleton embedded in flowstone, probably an inhumation that got caught up in an active flowstone event. These circumstances prevented detailed recording, but the on-site impression of large bones suggests an adult male (Bulbeck et al. 2011). A cranial fragment from the skeleton was of sufficient quality for an AMS date of $1000 \pm 25$ B.P. (987-1149 cal A.D., 95\% probability range) (Table 5).

\section{GUA LAMPETIA}

Gua Lampetia, which lies in the part of the study region traditionally occupied by Routa (Bungku) speakers (Mead 1999), includes an east and a west chamber, both roomy and well lit (Fig. 7). In the east chamber, human bones including 17 crania (all adult apart from one teenager), leg bones, and pelves were found stored on a boulder, and a large collection of sherds from imported, sixteenth- to nineteenth-century ceramics was found on another boulder in the west chamber (Bulbeck et al. 2011).

Both of the $\mathrm{m}^{2}$ test pits (A and B) excavated in the west chamber produced fragmentary human remains, sherds of earthenware and imported ceramics, glass beads, and bronze ornaments in the upper artificial levels. The human teeth allow a minimum of four children (three years old to teens) and four adults to be identified. Two 


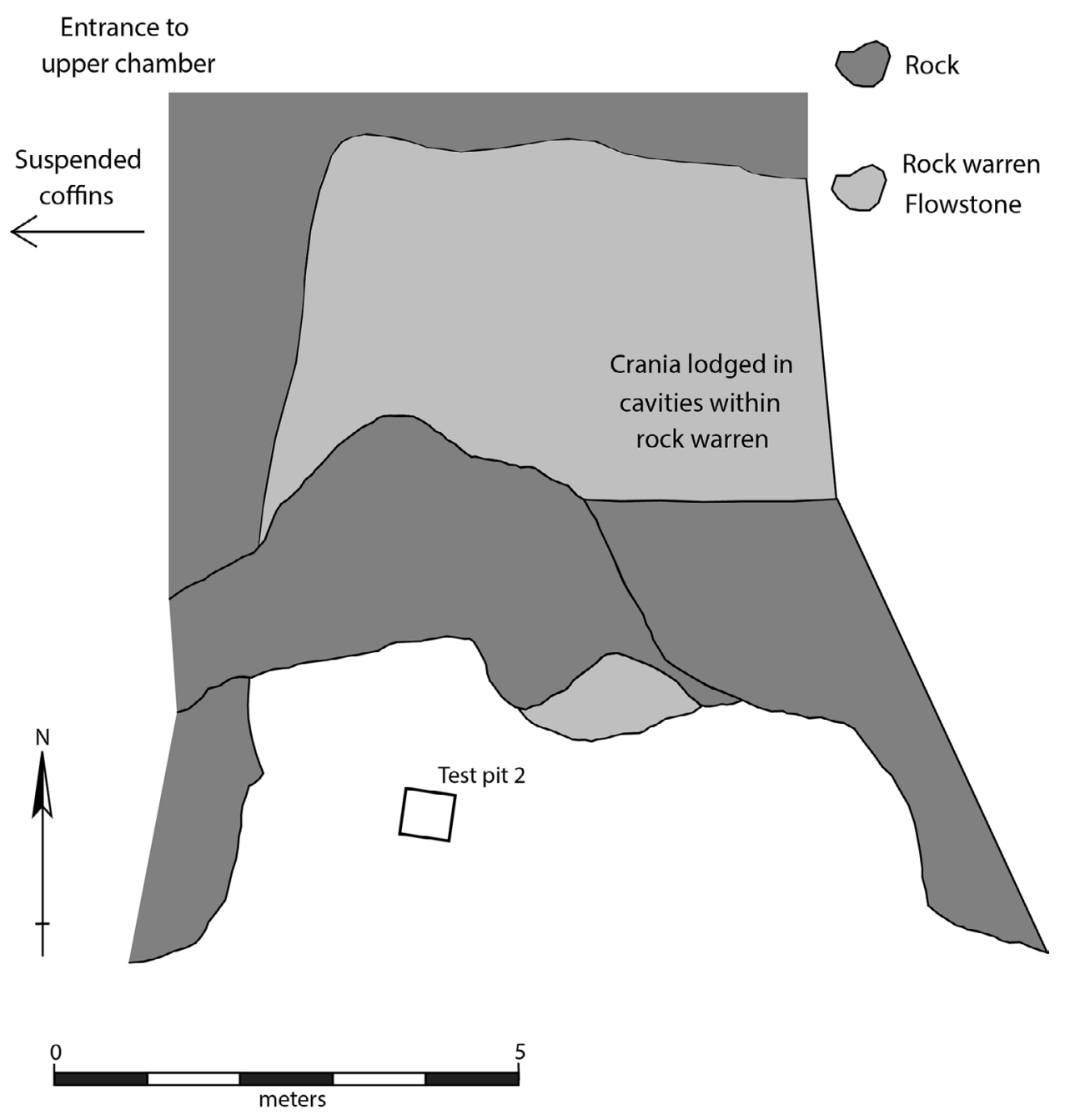

Fig. 6. Gua Andomo lower chamber showing location of Test pit 2.

of the adults have carious lesions, while another adult and the teenager have betelstained teeth. The other skeletal parts include cranial, vertebral, scapula, arm-bone, hand, sacral, pelvic, leg-bone, and foot fragments, and manual and pedal extremities. The imported ceramics date to between the fifteenth/sixteenth and nineteenth/ twentieth centuries (Table 4). The excavations also yielded traces of earlier habitation including ocher and three chert artifacts from Test pit A and some earthenware pottery found near the base of Test pit B.

The excavation of Test pit A was extended so as to remove a large earthenware mortuary jar revealed in the southwest corner. The jar has a date of A.D. $1140 \pm 60$ from both thermoluminescence and optically stimulated luminescence (OSL) for the jar body (UW2870) and an OSL date of A.D. $900 \pm 120$ for the jar cover (UW2871). The two dates overlap at their 95 percent probability range. Taking into account the 
Table 4. Imported Ceramic Sherds Excavated at Gua Andomo and Gua Lampetia

\begin{tabular}{|c|c|c|c|c|}
\hline CERAMIC TYPE & VESSEL FORM & $\begin{array}{l}\text { ESTIMATED AGE } \\
\text { (CENTURIES A.D.) }\end{array}$ & $\begin{array}{c}\text { GUA } \\
\text { ANDOMO }\end{array}$ & $\begin{array}{c}\text { GUA } \\
\text { LAMPETIA }\end{array}$ \\
\hline Vietnam brownware & $\begin{array}{l}\text { Jarlet/covered } \\
\text { bowl }\end{array}$ & $14 / 15 ?$ & 1 & - \\
\hline Ming celadon & Bowls, plate & $14-16$ & 3 & - \\
\hline Vietnam celadon & Bowl & $15 / 16$ & 1 & - \\
\hline Ming whiteware & Bowl & $15 / 16$ & 一 & 1 \\
\hline Sawankhalok brownware* & Martavan & 16 & 1 & - \\
\hline Ming red overglaze & Bowl & 16 & - & 1 \\
\hline Ming whiteware & Bowl & $16 / 17$ & 1 & - \\
\hline Thai brownware* & Martavan & $16 / 17$ & 2 & 2 \\
\hline Vietnam celadon & Jar & $16 / 17$ & 1 & - \\
\hline Vietnam? unglazed & Unidentified & $16 / 17$ & - & 1 \\
\hline Brittle (East Asian)* & Martavan & $16 / 17 ?$ & 2 & 1 \\
\hline Coarse brown (Thailand/Cambodia)* & Martavan & $16 / 17$ & 1 & - \\
\hline Guangdong brownware/blackware* & Martavan & $16-19$ & 8 & 1 \\
\hline Vietnam brownware* & Martavan & $18-19$ & 9 & 一 \\
\hline Qing blue-and-white & Bowls, plate & 19 & - & 3 \\
\hline $\begin{array}{l}\text { European (finer classification not } \\
\text { attempted) }\end{array}$ & Bowls, plate & $19-20$ & 9 & 4 \\
\hline
\end{tabular}

* Martavan categories defined by Harrisson (1990).

Table 5. Indicators of the Quality of Bone Collagen* from Gua Andomo (SANU 346I9)

\begin{tabular}{ll}
\hline COLLAGEN QUALity ASSURANCE & \multicolumn{1}{c}{ DATA } \\
\hline Collagen yield & $67.4 \mathrm{mg}, 6.5$ weight $\%$ \\
$\% \mathrm{C}$ & $36.8 \%$ \\
$\mathrm{C}: \mathrm{N}$ & 3.3 \\
$\delta^{13} \mathrm{C}$ & $-19.8 \%$ \\
$\delta^{15} \mathrm{~N}$ & $7.4 \% 0$ \\
\hline
\end{tabular}

* See note to Table 2 .

technical complexities associated with the dates, the most cautious approach would be to date the probable age of the jar burial to A.D. 900-1200. The jar contained the commingled remains of five individuals (three young children, an adult male, and an adult female) as well as a marine shell ring and bone pendant. The five individuals were identified on the basis of the dental remains, supported by analysis of the cranial, mandibular, clavicle, scapula, arm-bone, pelvic, and leg-bone fragments, and the manual and pedal extremities. Both adults showed betel-nut staining of their teeth.

The extended burial of a young male on the verge of adulthood was found in stratigraphic position beneath the jar, its skull dislodged by the interment of the jar. This extended inhumation would be older than the jar burial, but how much older is not possible to determine, because analysis of the poorly preserved bone showed there was not enough collagen for reliable ${ }^{14} \mathrm{C}$ dating. 


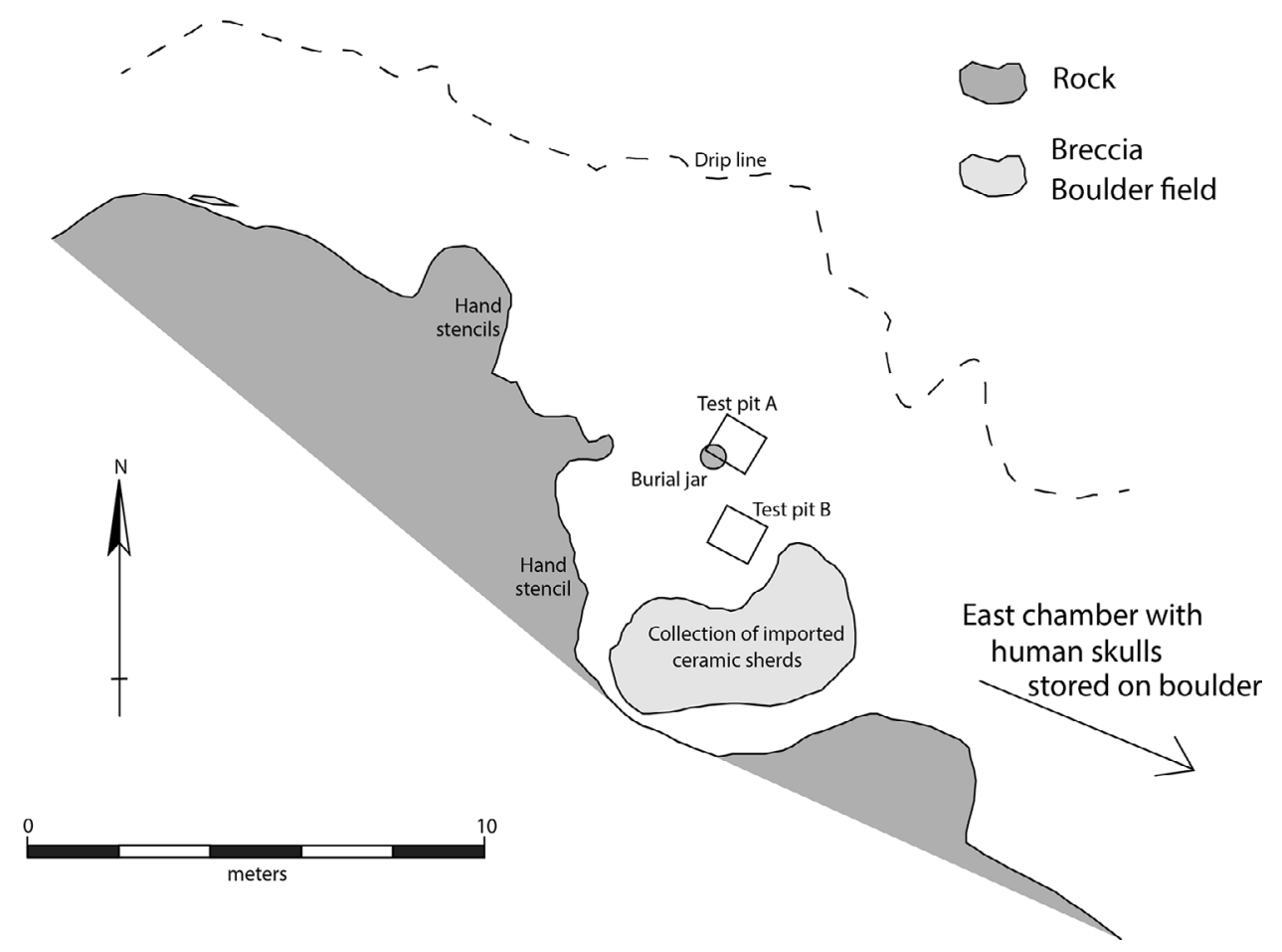

Fig. 7. Gua Lampetia west chamber showing location of Test pit A and Test pit B.

\section{CAVES WITH EXCAVATIONS LACKING MORTUARY REMAINS}

Excavations at two rock shelters near Walandawe named Gua Sambagowala and Gua Mo'o hono are relevant to our analysis. Both were test-pitted with $1 \mathrm{~m}^{2}$ excavations to a depth of several meters. Neither produced distinct burials, but the surface collection from Gua Sambagowala contained mortuary remains similar to those excavated from Gua Andomo and Gua Lampetia. Gua Sambagowala and Gua Mo'o hono echoed Gua Talimbue in indicating that preceramic habitation lasted until at least the second millennium B.C. and that the site continued to be used in recent centuries. The pottery in Square A at Gua Sambagowala was limited to a few sherds in the top $10 \mathrm{~cm}$ AL, beneath which (at $25 \mathrm{~cm}$ depth) was a charcoal AMS date of $3297 \pm 29$ B.P. (D-AMS 001988, 1637-1504 в.C. calibrated, 95\% probability range). The pottery assemblage from Gua Mo'o hono is quite substantial, but it cannot be dated any earlier than the first millennium A.D. because it appears at a depth about halfway between dates of about A.D. 1450 at AL 5 and 1800 B.C. at AL 13 (Table 6).

\section{CAVE EXCAVATION SUMMARY IN LOCAL CONTEXT}

The mortuary remains found at Gua Andomo and Gua Lampetia correspond well to Grubauer's observations of "Tolambatu" mortuary practices. Intact crania and other large bones were lodged on rock surfaces or stored in coffins, as at the mortuary cave that Grubauer visited. The identifiable individuals excavated from the deposit consist 
Table 6. Distribution of Pottery in Gua Mo“o Hono Test Pit A Upper Spits

\begin{tabular}{|c|c|c|c|}
\hline $\begin{array}{l}\text { ARTIFICIAL } \\
\text { LEVELS }\end{array}$ & $\begin{array}{l}\text { INFERRED } \\
\text { APPROXIMATE } \\
\text { CHRONOLOGY }\end{array}$ & $\begin{array}{l}\text { POTTERY } \\
\text { QUANTITY }\end{array}$ & RELEVANT ASSOCIATIONS \\
\hline $1-5$ (to $50 \mathrm{~cm}$ ) & $\begin{array}{l}\text { A.D. } 1450- \\
1950\end{array}$ & $\begin{array}{l}320 \text { sherds } \\
(392 \mathrm{~g})\end{array}$ & $\begin{array}{l}\text { European sherd, bottle glass, Chinese sherd, } \\
\text { charcoal at } 50 \mathrm{~cm} \text { (D-AMS 001622) } 450 \pm 24 \\
\text { B.P. calibrating to A.D. } 1420-1466 \text { ( } 95 \% \text { interval) }\end{array}$ \\
\hline 6-9 (to $90 \mathrm{~cm})$ & A.D. $1-1450$ & $\begin{array}{l}428 \text { sherds } \\
\quad(497 \mathrm{~g})\end{array}$ & $\begin{array}{l}\text { Polished stone tip and box fragment; AL } 9 \text { pottery } \\
\text { just } 2 \text { sherds, probably displaced from above }\end{array}$ \\
\hline $10-13$ (to $1.3 \mathrm{~m}$ ) & 2000-1 в.С. & Pre-pottery & $\begin{array}{l}\text { Charcoal at } 1.28 \mathrm{~m} \text { (D-AMS } 001623) 3452 \pm 26 \\
\text { B.P. calibrating to } 1879-1690 \text { B.C. (95\% interval) }\end{array}$ \\
\hline
\end{tabular}

of similar numbers of children and adults. With reference to Grubauer's account, the children would have have been carried to the caves for burial as corpses unaccompanied by coffins, while the adults would have been transported to the caves in biers that subsequently deteriorated and spilled their contents. This spillage would also account for the excavated material culture, which covers the range of mortuary goods described by Grubauer. About half of the imported ceramic sherds came from large stoneware jars, reminiscent of those described by Grubauer used for holding the remains of deceased aristocrats. The dates of the imported ceramics suggest an overall period of c. A.D. 1500-1900 for the mortuary tradition described by Grubauer.

However, the Towuti-Routa excavations also reveal a Palaeometallic mortuary sequence extending back to the early centuries A.D. The earliest documented mortuary practice involved direct burials in the cave floor, overlapping at around A.D. 1000 with the use of a large earthenware jar for communal burial. The total number of 4 Palaeometallic burials is small compared with the minimum number of 17 individuals excavated in association with the ethnohistorical cemeteries at Gua Andomo and Gua Lampetia. While the quantity of Palaeometallic burials is insufficient to infer the establishment of Palaeometallic cemeteries, the excavated area (about $9 \mathrm{~m}^{2}$, from just 5 sites) is too small to rule out their existence.

The mild to severe oral pathology of the adult jaws and dentitions of both the Palaeometallic and ethnohistorical burials, along with betel-nut staining on about one-third of the teenager/adult dentitions, points to an agriculturally based subsistence economy. Site survey in 2011 documented one open site-Laraowa - that may be of Palaeometallic antiquity. Local farmers donated a stone barkcloth beater and a corroded iron bushknife blade from the site and reported coming upon potsherds at around $50 \mathrm{~cm}$ depth. The c. A.D. 1500-1900 phase is certainly represented by some large open sites documented during the 2011 survey. These include the Polihe fort, with a perimeter of earth ramparts and a hill line enclosing an extensive area of about 3 ha, and Kowatan ("place of artisans"), with ironworking debris of early twentiethcentury and older antiquity (O'Connor et al. 2014).

\section{EARTHENWARE POTTERY}

Representative samples of earthenware pottery have been documented for Gua Talimbue and Gua Mo'o hono and large quantities have been excavated from Gua Andomo and Gua Lampetia. The earthenware fabric from all sites is similar. The pre- 
dominant inclusions (where present) consist of white speckles or grains, presumably weathered from local limestone and naturally present as grit in the clays that can be found along the Towuti-Routa streambeds. Unfortunately, time restrictions limited the documentation of the Gua Andomo assemblage or the Gua Lampetia pottery (apart from the burial jar). In the latter case, limited sampling would seem to explain why the sherds with visible traces of their manufacturing technique reflect paddleand-anvil finishing less often than alternative observed techniques (hand modeling, molding in a basketry casing, use of a slow wheel for finishing jar apertures), whereas paddle-and-anvil finishing dominated the other assemblages (Table 7).

The decorations on the Gua Talimbue pottery from all five excavated squares follow the same ornate style (Fig. 8), although the proportion of sherds that are decorated is higher in the vicinity of the extended burial than in Square B and Square E. The most common motifs in the excavated sample either have archaeological parallels with the pottery decorations at Gua Mo'o hono or ethnographic parallels with the central Sulawesi highlands (Table 8). Not all of the Gua Talimbue pottery motifs were recorded at Gua Mo'o hono, but this could be explained by the more diverse decorative repertoire at Gua Talimbue, which, in turn, could reflect the ritual nature of its pottery compared with the habitation context of Gua Mo'o hono. Interestingly, the two most common motifs are also depicted on a large mortuary jar from Gua Rukuo (Fage 2014), which lies in the Matarombeo Massif, a Bungku-speaking area approximately $50 \mathrm{~km}$ to the east (Mead 1999).

The large Gua Lampetia burial jar, dated to around A.D. 1000, is a remarkable artifact (Fig. 9). When intact, the jar body would have weighed about $5.5 \mathrm{~kg}$ and the cover $850 \mathrm{~g}$; the height and girth of the body would have been 50 and $70 \mathrm{~cm}$, respectively. The body would have gleamed golden-brown inside and outside from its comprehensive dammar coating. The cover had an external dammar coating over its paddle-impressed, shallowly crenulated decorations (Fig. 10). The inside surface is rough and black from being fired in a reducing environment.

At both Gua Lampetia and Gua Andomo, the excavations of the ethnohistorical mortuary disposals produced a greater quantity of local earthenware than imported ceramics. At Gua Lampetia, there was over $1.5 \mathrm{~kg}$ of local earthenware (not including the large intact jar), but only about $200 \mathrm{~g}$ of imported ceramics. Earthenware pottery included large jars, some with appliqué zigzags along the neck, and smaller vessels, a few decorated with punctate dots, incisions, and paddle-impressed crests (Fig. 11). The punctate-dot motif may have been quite long-lasting, since it is also present on the stratigraphically deepest pottery from Gua Lampetia Test pit B, deposited well before the ethnohistorical burials, and also on the Gua Talimbue and Gua Mo'o hono pottery.

At Gua Andomo, excavated local earthenware amounted to some $13 \mathrm{~kg}$, dwarfing the $600 \mathrm{~g}$ of imported ceramics. Large jars with a brown to black coloration, often polished or coated with dammar, and undecorated apart from occasional horizontal incisions, dominate the earthenware. As with the imported martavans, the large earthenware jars at Gua Andomo were probably used for holding the remains of the deceased, but presumably only commoners.

A resinous coating that appears to be dammar was recorded on just a small proportion $(<2 \%)$ of the Gua Talimbue sherds, but 12 percent or more of the other pottery assemblages (Table 7). One possible explanation for this difference is that a resinous coating would tend to mask fine decorations and so was avoided as a surface finish for the Gua Talimbue pottery. Application of a red slip was also unrecorded for Gua 


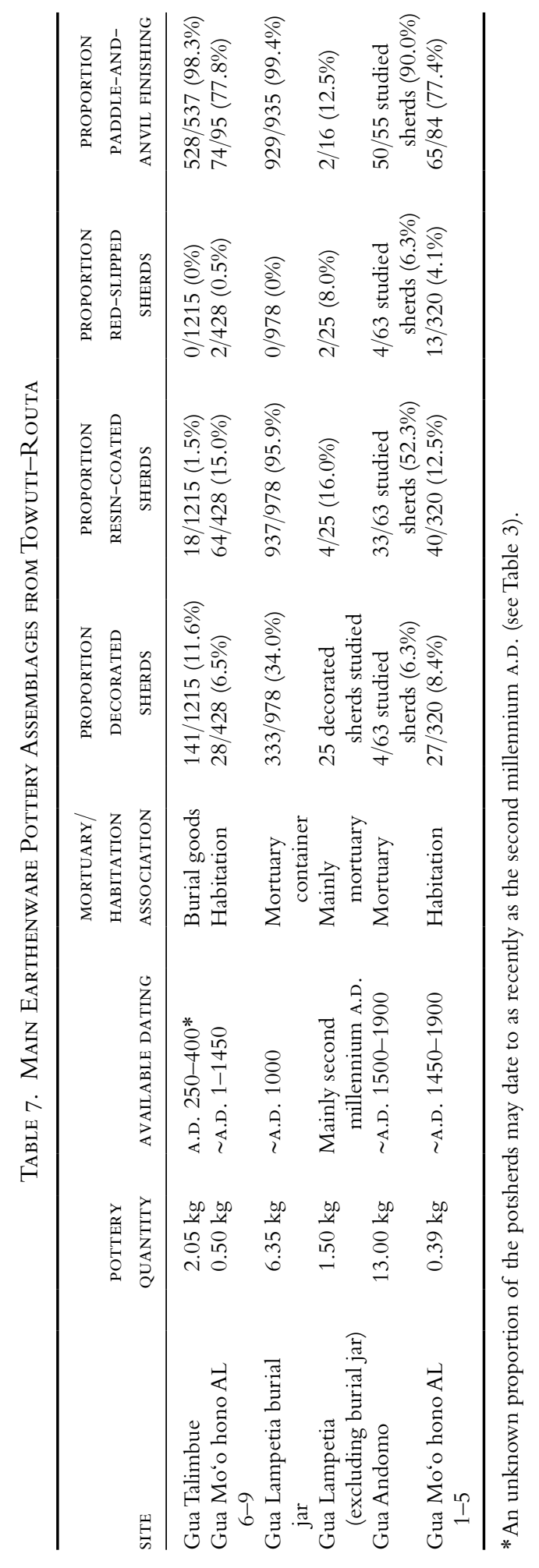




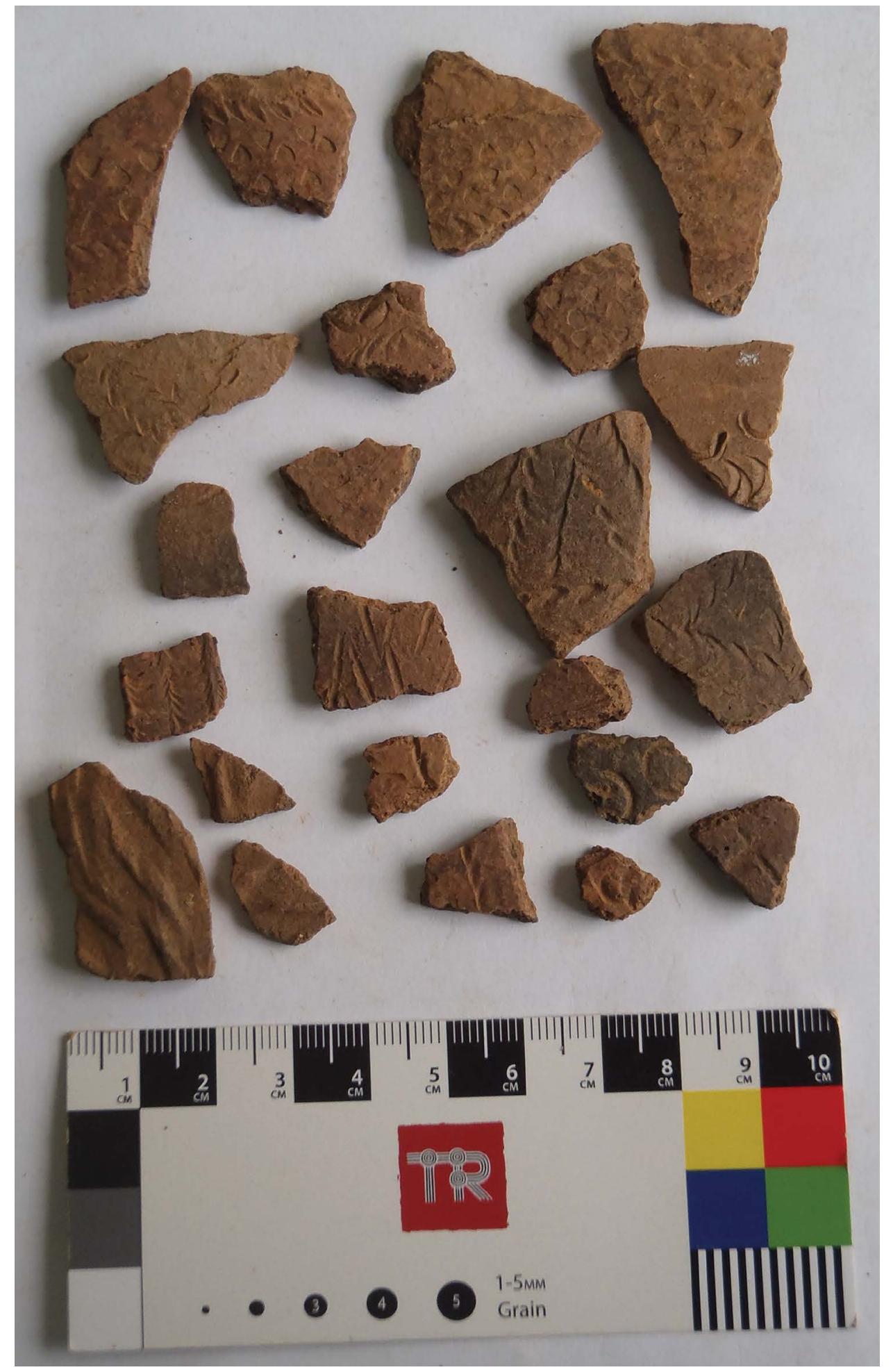

Fig. 8. Decorated earthenware pottery from Gua Talimbue, Square A, AL 6. 
Table 8. Most Common Gua Talimbue Decorative Motifs and Their Parallels

MOTIF

PARALLEL

Semicircles arranged in compositions*

Lines of commas that resemble fern leaves*

Series of dots in lines or fields

Panels of rounded triangular indentations

Vertical paddle-impressed crests

Gua Mo'o hono AL 6

Wooden panel, Lake Poso, Central Sulawesi (Grubauer 1913:442)

Gua Mo“o hono AL 5

Wooden front doors, Lemo, Tana Toraja, northern South Sulawesi (Grubauer 1913: fig. 309) Gua Mo‘o hono AL 3-7

*Also depicted on the sherds of a mortuary jar from Gua Rukuo (Fage 2014).

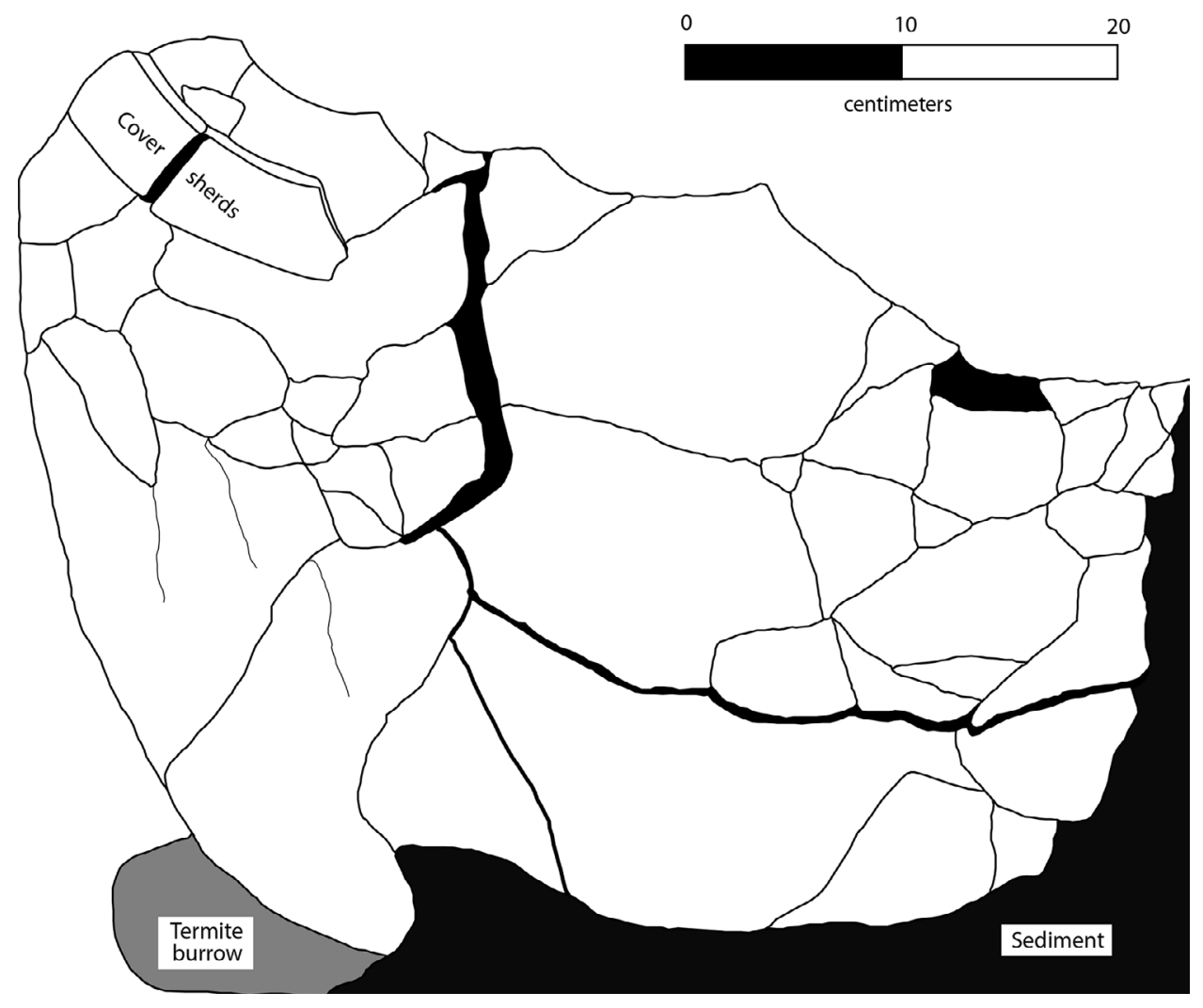

Fig. 9. Large burial jar at Gua Lampetia, sketched during excavation.

Talimbue, but it was similarly rare for the other assemblages, perhaps reaching a prevalence rate of about 5 percent after A.D. 1500. In any case, the copious use of dammar for the Gua Lampetia burial jar marks its local availability in large quantities by approximately A.D. 1000 .

These observations are offered largely as a basis for future research. Further analysis of the earthenware pottery for socioeconomic information on Towuti-Routa would 


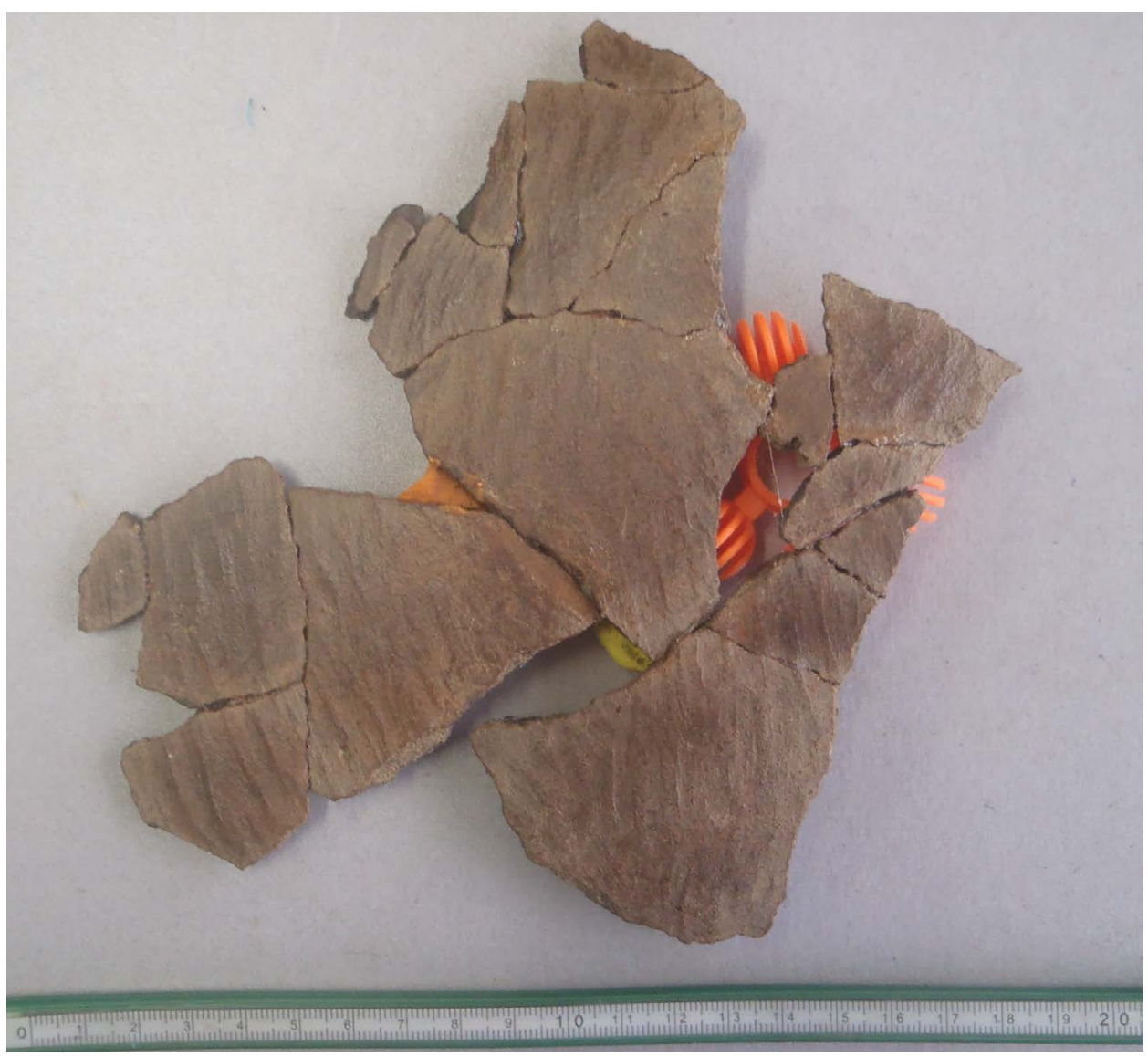

Fig. 10. External surface of the cover of large burial jar from Gua Lampetia.

be premature in view of the scarcity of other well-documented earthenware sequences in central Sulawesi. However, the earthenware pottery from Old Luwu has been described in sufficient detail to demonstrate its marked differences from TowutiRouta. The first millennium A.D. pottery from Sabbang Loang and Katue has a very low proportion of decorated sherds $(0.2 \%$ at both sites). The comma shapes observed on two Katue sherds provide the only point of similarity with the most common Gua Talimbue motifs (Bulbeck 2008). The analyzed earthenware pottery from Utti Batue, the palace center of the Bugis kingdom of Luwu between the fifteenth and sixteenth centuries A.D., includes an imitation martavan with horizontal incised lines similar to the Gua Andomo jars, as well as rates of sherds with a red slip (3\%) or suspected resin coating $(28 \%)$ similar to Towuti-Routa second millennium A.D. assemblages. However, these Towuti-Routa assemblages do not include any matches for the "arabesque" designs observed on some Utti Batue sherds, nor any sign of the "soft pottery" class that accounts for around 10 percent of the earthenware manufactured in Old Luwu between the fourteenth and seventeenth centuries A.D. (Bulbeck 2009:9, table 1.2; Bulbeck et al. $2007: 136-137)$. 


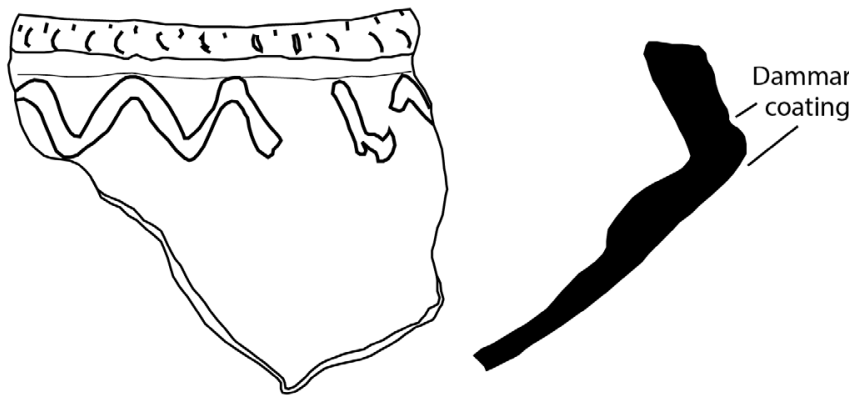

Large jar with notched rim and appliqué zigzag band above shouder, Test pit B, AL 1
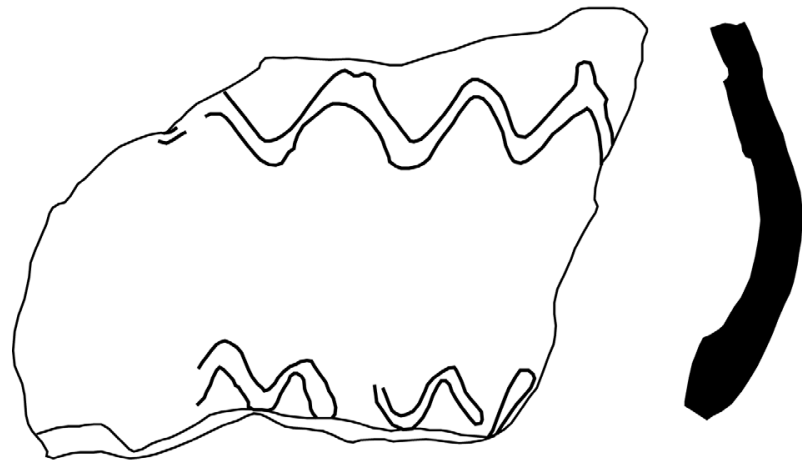

Large jar with two appliqué zigzag bands at neck, Test pit A, AL 2
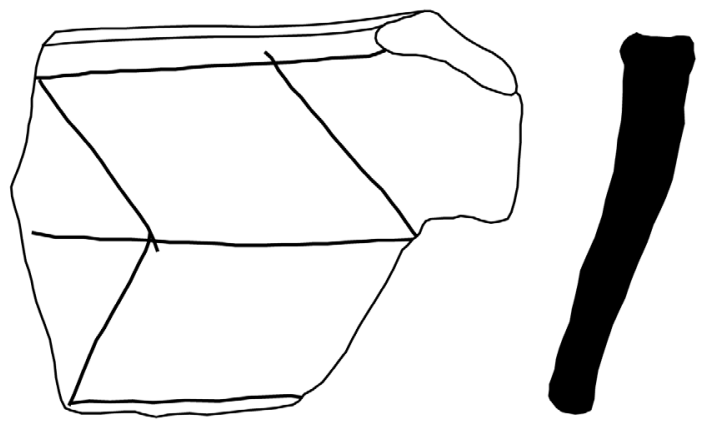

Large jar with incisions at rim and neck, Test pit A, AL 2

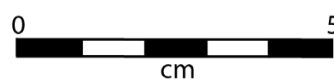

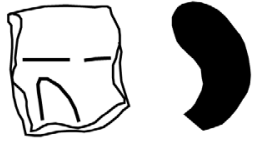

Small jar with incisions at neck, Test pit A, AL 2

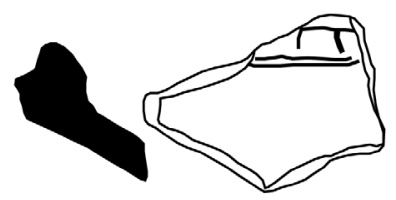

Cover with appliqué band, Test pit A, AL 2

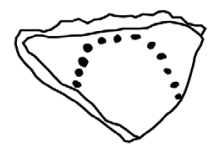

Body sherd with punctate design, Test pit B, AL 1

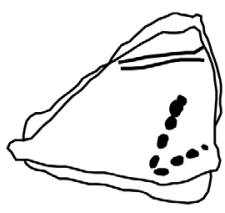

Body sherd with incisions and punctate design, Test pit B, AL 10

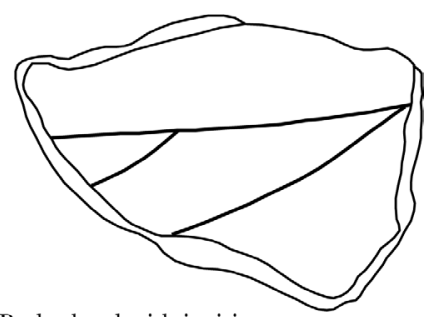

Body sherd with incisions,

Test pit A, AL 2

Fig. 11. Decorated earthenware sherds from Gua Lampetia Test pit A and Test pit B.

BEADS

The great majority of the 336 beads that were excavated are glass. Only 5 were identified as made of other materials, including a bronze bead and a Nassarium sp. shell bead from Gua Talimbue, and an agate bead and two Nassarium sp. shell beads from 
Gua Andomo. The possible source of the Nassarium sp. beads is unclear because in Sulawesi this genus includes marine, brackish, and freshwater species. The bronze bead may have been manufactured in Sulawesi, whereas the agate and glass beads would have been imported from overseas.

Project scheduling and funding restrictions prevented chemical analysis of the glass beads, so their coverage here focuses on metrical and visual attributes. The recorded measurements include the length of the bead (the axis along which the bead would have been strung) and the (maximum) diameter perpendicular to the bead's length. The color classes used here are those from the Munsell standard charts, mostly the soil-color chart, but also the rock-color chart for the most brightly colored beads.

The 48 Talimbue glass beads, all associated with the extended burial, are less diverse than the 158 Andomo and 125 Lampetia glass beads. All of the Talimbue examples can be classified as "Indo-Pacific drawn monochrome glass beads," which were produced in Southeast Asia between the early centuries and the twelfth century A.D. (Francis 1999: 94) (Fig. 12). They range in length from 1.1 to $4.8 \mathrm{~mm}$ and in diameter from

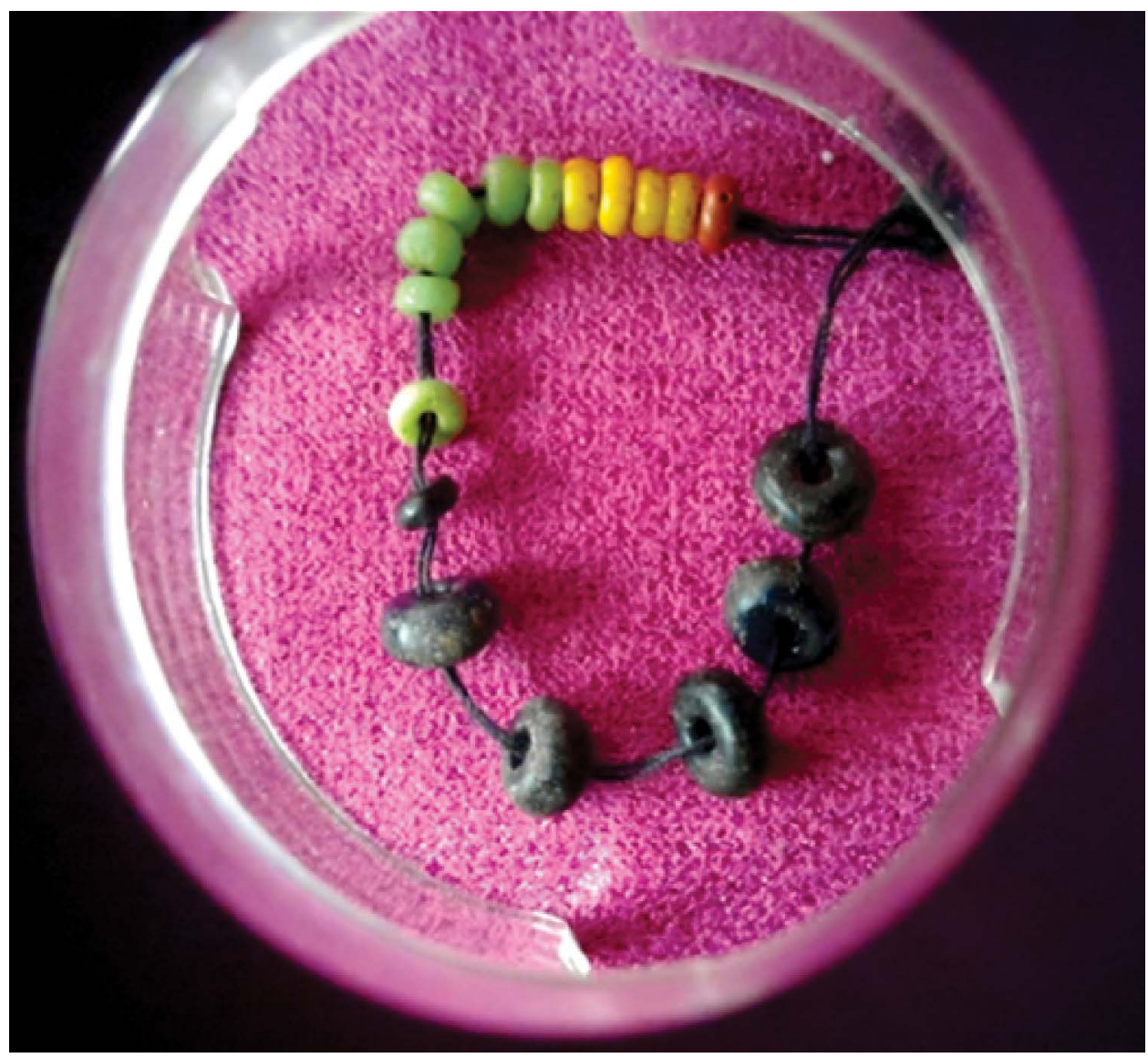

Fig. 12. Glass beads (counterclockwise from top right: red, yellow, green, black) from Gua Talimbue, Square A, AL 10. 
Table 9. Summary of the Shapes of the Towuti-Routa Beads

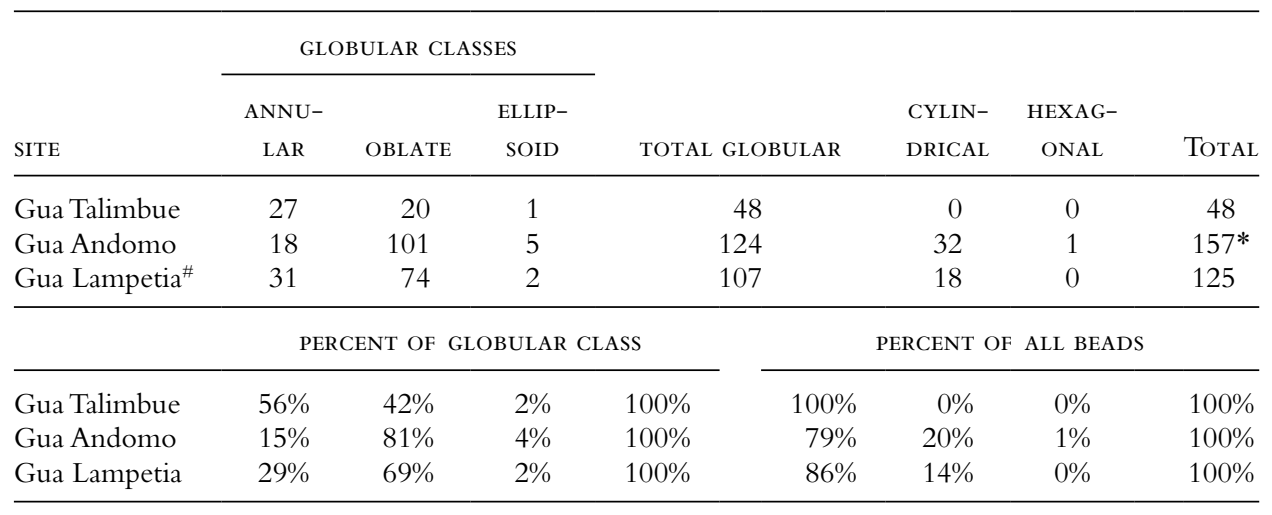

* Excludes one glass bead too fragmentary for its shape to be discerned; \# includes one annular and five oblate beads from AL 4-6 (stratigraphically beneath the other beads).

2.3 to $7.9 \mathrm{~mm}$. Many of the Andomo and Lampetia examples can also be assigned to the Indo-Pacific class, but they are complemented by beads that continued to be produced for export after A.D. 1200, including wound beads and small, drawn monochrome "seed beads" that were made across Eurasia (Francis 1999:67). The 382 Andomo/Lampetia wound beads include nine specimens with a length between 6.5 and $12 \mathrm{~mm}$, clearly distinguishing them from the Talimbue beads, while the Andomo/ Lampetia seed beads include 32 specimens with a diameter less than that recorded for any of the Talimbue beads.

The range of shapes of the Talimbue glass beads is also less than their Andomo and Lampetia counterparts (see the bead shape table in Adhyatman and Arifin 1996:154157). The two main shape classes are globular and cylindrical, respectively distinguished by whether the diameter is clearly rounded or relatively constant for the length of the bead. All of the Talimbue glass beads are globular, but this is not the case with the approximately 15-20 percent of the Andomo and Lampetia beads that are cylindrical or, in one case, hexagonal (Table 9). Within the globular class, the modal shape for the Talimbue beads is flat or "annular," defined here as having a diameter at least 1.7 times the bead length. But for Gua Andomo and Gua Lampetia, including the 6 stratigraphically deepest Lampetia beads, rounded or "oblate" is the most common shape, defined by having a diameter between 80 and 170 percent of the bead length. At all three sites, just a small proportion of the beads are "ellipsoid," with a diameter less than 80 percent of the bead length.

There are also color differences between the Talimbue and the other beads. The most common color classes for the Talimbue beads are green, yellow, or black; none are brown/olive, pink, or white (Table 10). With the Andomo and Lampetia beads, about half are classified as gray based on a subdued greenish tinge equating to light to dark greenish gray; smaller proportions have a brown/olive, pink, or white coloration. This description also applies to the six stratigraphically deepest beads from Gua Lampetia, providing little reason to distinguish them from the other Andomo/Lampetia beads.

Based on these observations, the Talimbue and the Andomo/Lampetia beads constitute distinct assemblages. This corresponds to the early first millennium A.D. date for 
BULBECK ET AL. - MORTUARY CAVES AND THE DAMMAR TRADE

Table io. Summary of the Colors of the Towuti-Routa Beads

\begin{tabular}{llllllllll}
\hline \multirow{2}{*}{ SITE } & & & & & \multicolumn{5}{c}{ BROWN/ } \\
WHITE & PINK & YELlOW & RED & GREEN & BLUE & OLIVE & GRAY & BLACK \\
\hline Gua Talimbue & 0 & 0 & 10 & 3 & 21 & 1 & 0 & 3 & 10 \\
& $(0 \%)$ & $(0 \%)$ & $(21 \%)$ & $(6 \%)$ & $(44 \%)$ & $(2 \%)$ & $(0 \%)$ & $(6 \%)$ & $(21 \%)$ \\
Gua Andomo & 5 & 8 & 21 & 11 & 3 & 0 & 12 & 75 & 23 \\
& $(3 \%)$ & $(5 \%)$ & $(13 \%)$ & $(7 \%)$ & $(2 \%)$ & $(0 \%)$ & $(8 \%)$ & $(48 \%)$ & $(15 \%)$ \\
Gua Lampetia & $19 *$ & 5 & 7 & 2 & $5 *$ & 0 & $11 *$ & $71 *$ & $5 *$ \\
& $(15 \%)$ & $(4 \%)$ & $(6 \%)$ & $(2 \%)$ & $(4 \%)$ & $(0 \%)$ & $(9 \%)$ & $(57 \%)$ & $(4 \%)$ \\
\hline
\end{tabular}

* Colors recorded (gray twice) for beads from AL 4-6 (stratigraphically beneath the other beads).

the Gua Talimbue burial and the late second millennium A.D. date for the majority of the Gua Andomo/Lampetia mortuary disposals.

\section{METALS}

Gua Talimbue produced two metallic items in close proximity to the extended burial: the bronze bead mentioned above, and an ear pendant, apparently of iron, with a hook at the top of the unphotographed side (Figure 13). Pendants of this variety seem to have had a long history of use in Towuti-Routa, since the Gua Talimbue pendant is similar to a middle ear pendant from Wawondula, then a Leoka (Mori) village, illustrated by Grubauer (1913: fig. 82).

The excavated metal ornaments from Gua Andomo and Gua Lampetia are all copper-based, either brass or bronze. All of them have parallels in the ethnography of Central Sulawesi, where traditional bronze metallurgy thrived during ethnohistorical times (van Heekeren 1958) (Table 11). They may indeed source to central Sulawesi given that site survey in Towuti-Routa recovered evidence only of local iron metallurgy (Bulbeck et al. 2011). Their antiquity would be the same as the c. sixteenth- to nineteenth-century mortuary disposals with which they are associated.

\section{COMPARISONS WITH OTHER ISEA SITES WITH SIMILAR MORTUARY REMAINS}

This section compares the burial customs of Towuti-Routa with other ISEA sites. ${ }^{3}$ Extended burials in the c. first millennium A.D. time range are the earliest mortuary practice documented for Towuti-Routa, but they were evidently preceded in Sulawesi by Neolithic extended inhumations, seen in the Oluhuta cave on Sulawesi's northern arm. Certainly, Neolithic extended inhumations date back to 1000 B.C. or earlier at caves in Borneo, Java, Sumatra, Peninsular Malaysia, and perhaps Flores. A shift from caves to open-air settings for the majority of extended burial sites can be dated to the first millennium A.D., as documented at numerous sites in Peninsular Malaysia, south Sumatra, Lomblen, and Luzon, though not Sulawesi (Table 12). In summary, the Towuti-Routa extended burials are not only unmatched in Sulawesi for the first millennium A.D. (per current documentation), their cave setting is atypical for extended burials of this age across ISEA in general.

Many of the grave goods from extended inhumations indicate a local capacity to make pottery and polished stone items and shell jewelry. These techniques are 


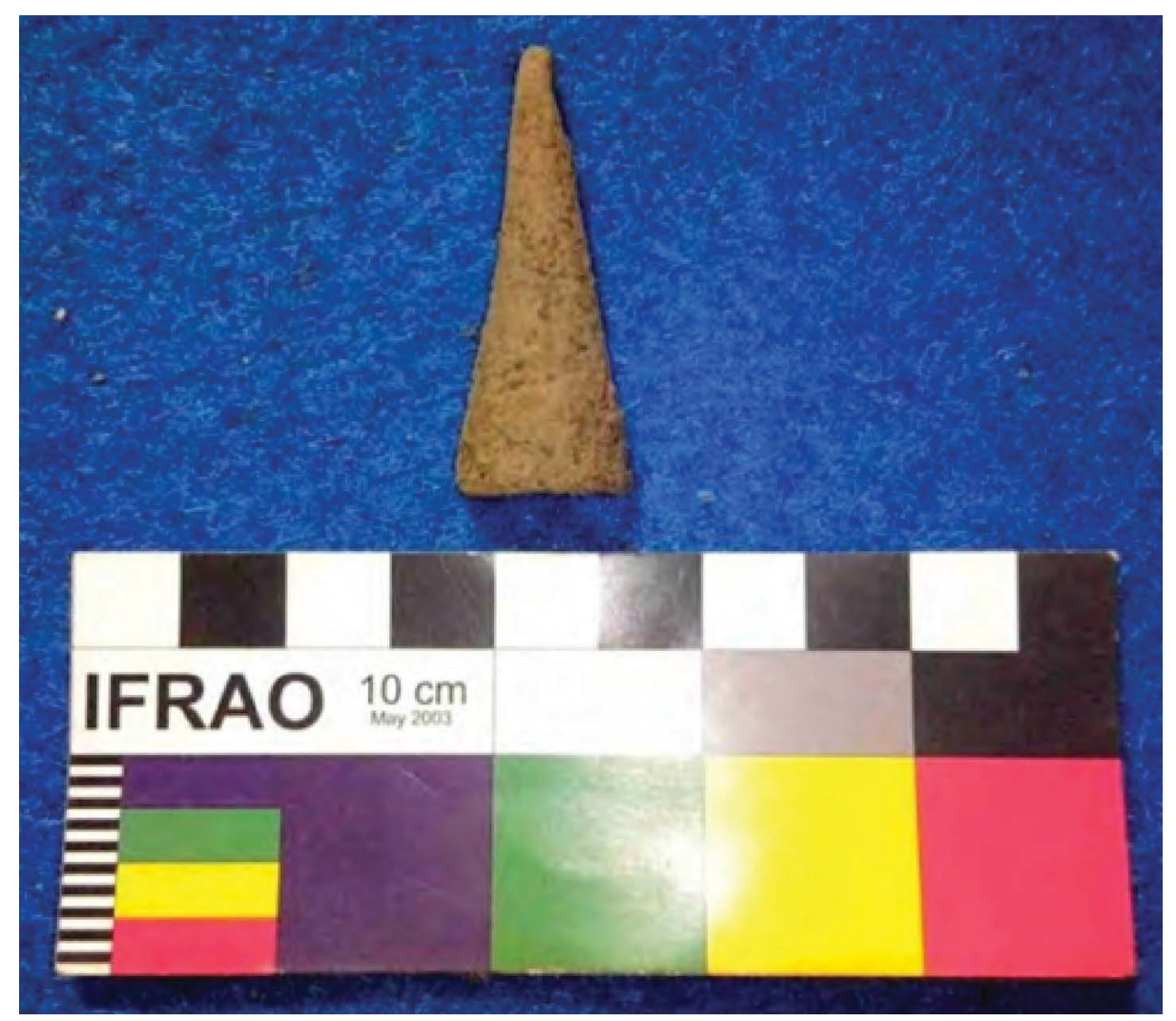

Fig. 13. Iron ear pendant from Gua Talimbue, Square C, AL 6.

Table i i. Excavated Metal Ornaments from Gua Andomo and Gua Lampetia

\begin{tabular}{|c|c|c|}
\hline OBJECT & PROVENANCE & ETHNOGRAPHIC PARALLEL \\
\hline Brass ringlet & Gua Andomo Test pit 2, AL 2 & Soroako, Lake Matano (Grubauer 1913: fig. 60) \\
\hline Brass wristlet & Gua Andomo Test pit 2, AL 2 & $\begin{array}{l}\text { Rampi, northern South Sulawesi (Grubauer 1913: } \\
\text { fig. 206) }\end{array}$ \\
\hline Bronze earring & Gua Andomo Test pit 2, AL 2 & Besoa, Central Sulawesi (Grubauer 1913: fig. 256) \\
\hline Bronze ringlet & Gua Andomo Test pit 2, AL 4 & Soroako, Lake Matano (Grubauer 1913: fig. 60) \\
\hline Bronze wristlet & Gua Andomo Test pit 2, AL 5 & $\begin{array}{l}\text { Rampi, northern South Sulawesi (Grubauer 1913: } \\
\text { fig. 206) }\end{array}$ \\
\hline Copper wristlet & Gua Andomo Test pit 2, AL 6 & Soroako, Lake Matano (Grubauer 1913: fig. 60) \\
\hline Bronze bangle & Gua Andomo Test pit 2, AL 9 & $\begin{array}{l}\text { Rampi, northern South Sulawesi (Grubauer 1913: } \\
\text { fig. 206) }\end{array}$ \\
\hline Bronze earplug & Gua Lampetia Test pit A, AL 1 & Soroako, Lake Matano (Grubauer 1913: fig. 60) \\
\hline Bronze earplug & Gua Lampetia Test pit B, AL 1 & $\begin{array}{l}\text { Besoa taiganja, Central Sulawesi (Grubauer 1913: } \\
\text { fig. 258) }\end{array}$ \\
\hline Bronze bangle & Gua Lampetia Test pit B, AL 1 & Soroako, Lake Matano (Grubauer 1913: fig. 67) \\
\hline Bronze ringlet & Gua Lampetia Test pit B, AL 1 & Soroako, Lake Matano (Grubauer 1913: fig. 60) \\
\hline
\end{tabular}


evidently associated with the southward spread of Austroasiatic languages to Peninsular Malaysia, and Malayo-Polynesian languages across ISEA (Bellwood 1997). To some degree, extended inhumations replaced an earlier practice of flexed inhumations (Bulbeck 2011; Lloyd-Smith et al. 2013; Noerwidi in press), but this on its own constitutes a poor candidate trait for marking cultural contact. Since the Neolithic examples appear as a wide geographic scatter with little indication of a dispersal route, extended inhumations register as a simple solution to disposal of the deceased (Fig. 14). The Neolithic and later inhabitants of ISEA practiced a great variety of mortuary practices, whether associated with extended inhumations or represented at other funerary sites (Valentin et al. 2015) (Table 12). Accordingly, despite their Neolithic precedents in North Sulawesi, there is little basis for invoking an external influence for Towuti-Routa extended inhumations.

The second mortuary practice documented for Towuti-Routa involved the burial of a large jar holding commingled mortuary remains at Gua Lampetia at around A.D. 1000. Large jars with secondary disposals occurred as a minor component of the Niah Cave Neolithic burials dating to around 1000 B.C. (Table 12). However, the great majority dates to the Palaeometallic and later, including all of those in sites dominated by large burial jars. The Palaeometallic appearance of open-air burial grounds with these large jars at locations as far apart as southern Sumatra, the Batanes Islands at the north of the Philippines, Sumba, and southwest Sulawesi suggests that they mark an archaeological "horizon" related to the spread of metallurgy and a burgeoning trade in exotic goods made of glass and jade in the early centuries A.D. (Bulbeck in press $b$ ). The immediate source of inspiration for the Gua Lampetia mortuary jar could have been Sabbang Loang in Old Luwu, with its large burial jars dated to the first millennium A.D. (Bulbeck and Caldwell 2000). Unfortunately, comparison of jar contents is not possible because the strongly acidic soils of Sabbang Loang would have dissolved any bone or shell interred in the jars.

The Gua Lampetia mortuary jar was presumably not a unique creation for TowutiRouta even though it is the only example recovered. Considerably more excavation in the study region would be required to develop a sense of whether large mortuary jars were a marginal phenomenon restricted to around A.D. 1000 or whether they played a systematic role. The organizational costs of maintaining the potting skills to make large mortuary jars would have been high. Obtaining the dammar to coat them (depending on how consistently this embellishment was applied) and incorporating them into local funerary rites would also have entailed high economic costs. A deeply ingrained perception of the benefits of Lampetia-style large jars would have been necessary for the production of these jars to have become a mainstream practice. They could constitute an antecedent for the ethnohistorical mortuary tradition if they were followed by a transition, during the early second millennium A.D., toward (1) surface disposal rather than burial, and (2) usage for individual rather than compound disposals.

However, given the lack of data for early second millennium A.D. mortuary practices in Towuti-Routa, drawing any relationship between the Gua Lampetia mortuary jar and the ethnohistorical mortuary tradition is hypothetical. Mortuary practices during this period for Old Luwu are well documented, but they were dissimilar to the Towuti-Routa ethnohistorical mortuary tradition. The prevailing practice along the coastal plain between the thirteenth and seventeenth centuries A.D. involved the cremation of the deceased and their burial along with often sumptuous possessions 


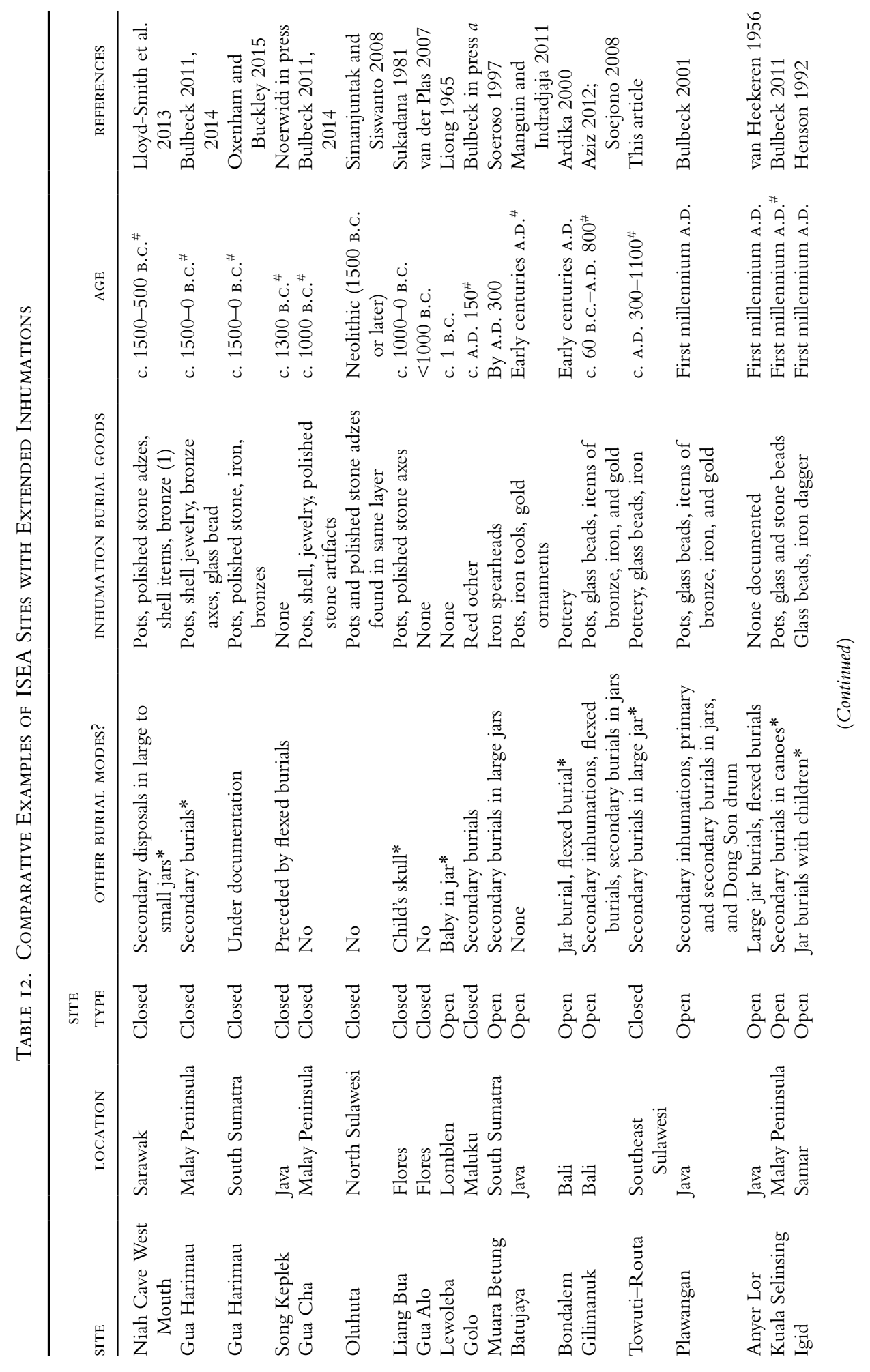




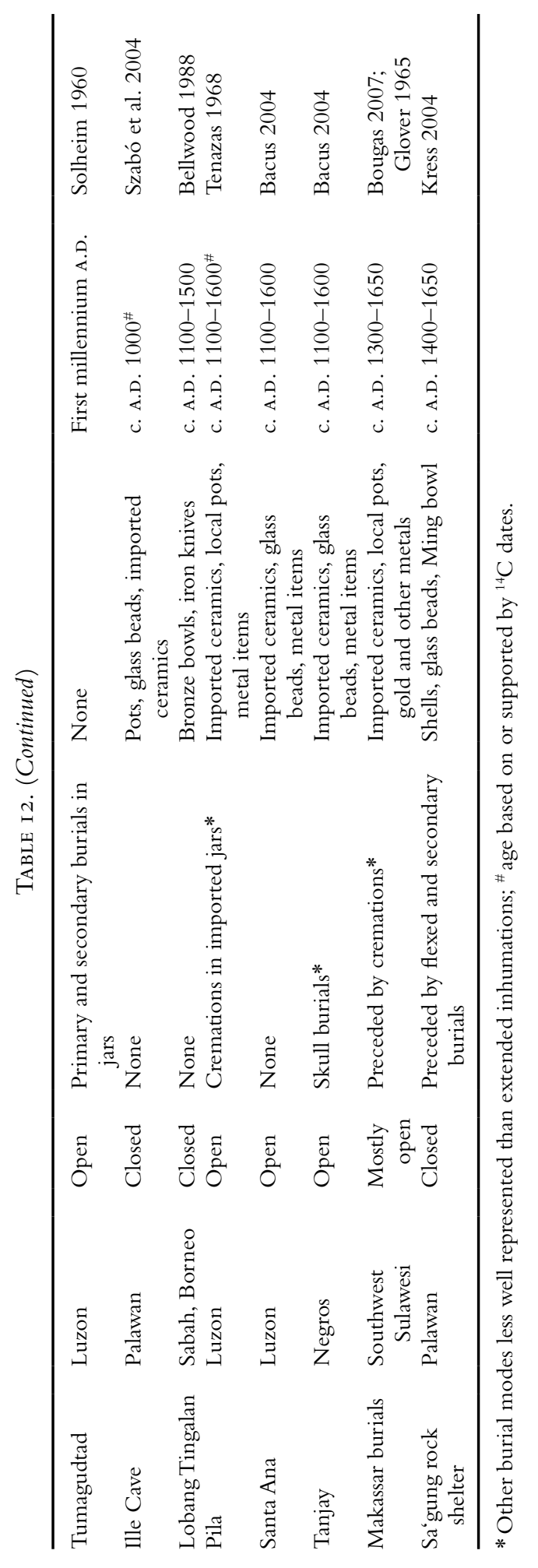




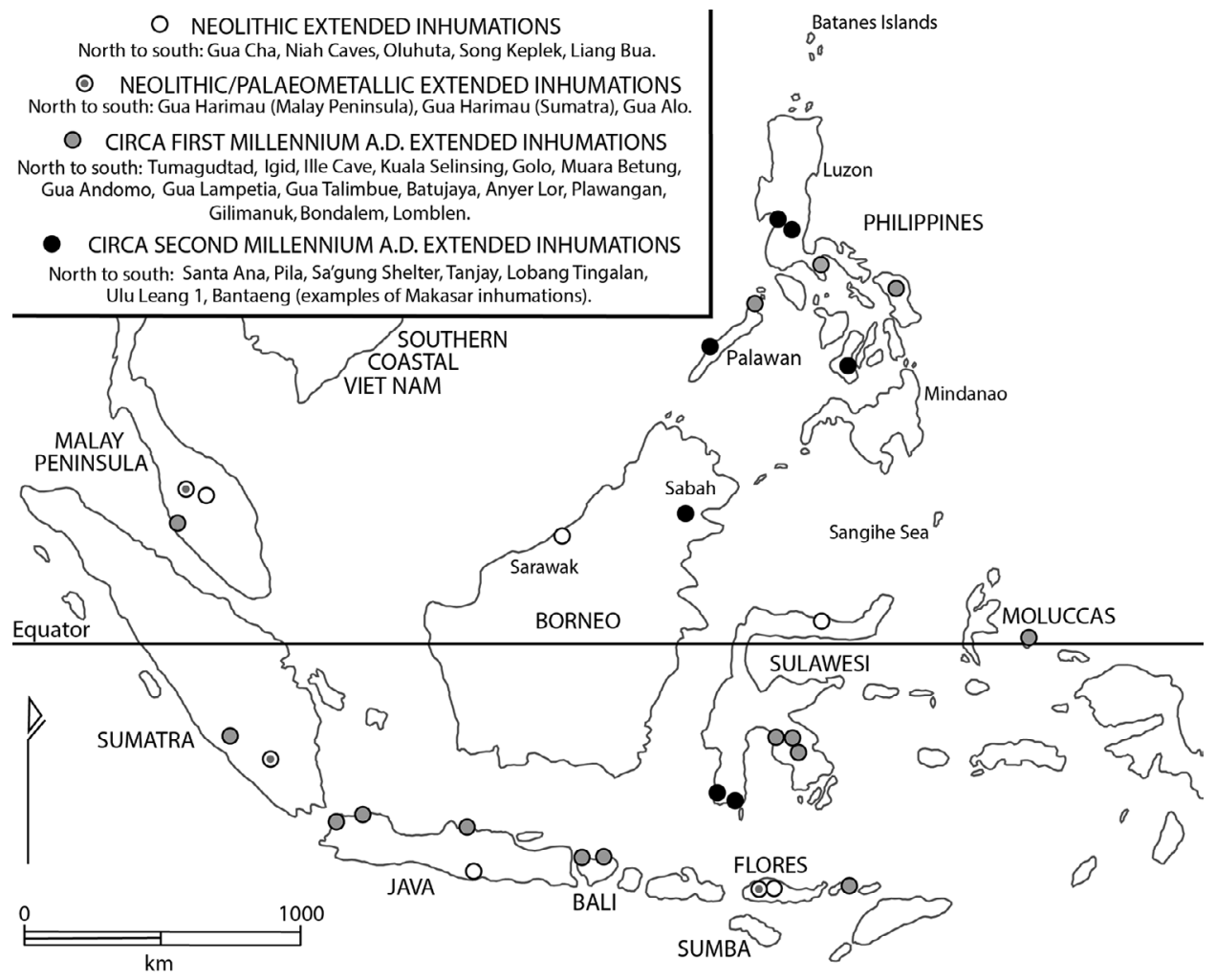

Fig. 14. ISEA sites with extended inhumations.

in martavans. Along the shores of Lake Matano between the twelfth and nineteenth centuries, the (sometimes cremated) deceased were buried with their possessions (Bulbeck and Caldwell 2000).

In terms of archaeological contents, a close match to the Gua Andomo/Lampetia ethnohistorical assemblages is provided by a complex of single-phase Palaeometallic cave sites distributed from southwest Sulawesi (Ulu Leang 2 and Leang Paja) to Sabah and southeastern Mindanao. These sites have yielded fragmentary human remains associated with metals, glass beads, and pottery sherds from large jars and accessory vessels (Bulbeck in press $b$ ). However, the lack of imported ceramics highlights their considerable antiquity and, accordingly, their unsuitability as an antecedent tradition for the Towuti-Routa ethnohistorical mortuary rites. A more promising candidate would be Lobang Tulang, part of the Niah Caves complex in Sarawak, even though it is not usually thought of as a jar burial site. In addition to a log coffin with secondarily disposed human bones, Lobang Tulang contained scattered human remains associated with a range of artifacts including glass, metal, and sherds of martavans and other imported ceramics dating to between the eleventh and fourteenth centuries A.D. (Harrisson 1958).

Interestingly, Grubauer (1913) speculated that the "Tolombatu" (Bungku) had immigrated from Borneo to pursue the Towuti-Routa dammar trade, to explain why their mortuary rituals, unique to Sulawesi, had ethnographic counterparts in 
northern/central Borneo. Although unremarked by Harrisson (1990), Lobang Tulang could serve as an antecedent for the ethnographically recorded Borneo mortuary practices, in which martavans dated to c. A.D. 1500-1900 played a central role. However, these practices were highly diverse. For instance, martavans were used as containers for the decomposing corpse as well as receptacles for skeletal relics. Futhermore, they were displayed not just in caves but also on wooden and stone funerary monuments (Bulbeck in press $b$ ). Given linguistic evidence against any Borneo connection with Towuti-Routa, the superficial similarities between the ethnohistorical mortuary traditions of northern/central Borneo and Towuti-Routa are best attributed to cultural convergence.

In summary, of the three mortuary practices documented for Towuti-Routa, large earthenware burial jars are the only practice that can be plausibly attributed to external influence. Their widespread appearance across ISEA including Old Luwu during the Palaeometallic seems to have prefigured their appearance in Towuti-Routa where, on the available data, extended inhumations were an older practice. Large burial jars may have been a precursor to the ethnohistorical mortuary rites, but such a possibility is speculative without data for the early second millennium A.D. funerary practices in the Towuti-Routa region.

Table 13 compares the Towuti-Routa funerary practices with their most similar counterparts documented at other ISEA mortuary site complexes. The Niah Caves and Baturong-Madai complexes of Borneo present the greatest number of similarities, although both lack true burial jars, and their chronological sequences differ from Towuti-Routa (and from each other). South Sumatra, north coastal Java and Bali, and southern Luzon resemble Towuti-Routa in their extended inhumations and burial jars of Palaeometallic antiquity, but differ in lacking the Towuti-Routa ethnohistorical mortuary tradition. Other comparisons in Table 13 show age discrepancies from Towuti-Routa for similar mortuary practices. In summary, notwithstanding a degree of permeability to wider social interactions, mortuary practices appear to have been fluid in response to local social imperatives at Towuti-Routa, as elsewhere in ISEA (Bulbeck in press b; Valentin et al. 2015).

\section{TOWUTI-ROUTA MORTUARY PRACTICES IN RELATION TO DAMMAR TRADE}

Use of dammar as a resin and fire-stick head presumably has ancient origins in Towuti-Routa; its commonplace application as a pottery coating is evident from the inception of the Gua Mo'o hono pottery sequence. Although the proportion of Gua Talimbue sherds with observed dammar coating is miniscule, some sort of local product would have been required to finance the importation of the glass beads and metal ornaments associated with the Gua Talimbue burial, and dammar is a plausible candidate. This last point raises the question of whether the shared practice of extended inhumations, at sites that respectively fall within the ethnohistorical distribution of Wiwirano, Bungku, and Padoe speakers, reflects the early establishment of a social network built on the collection of dammar for external trade. However, if the expansion of farming communities across Towuti-Routa occurred no earlier than the Palaeometallic, as the available data suggest, then the broad distribution of extended inhumations could simply reflect the mortuary custom of the founding settlers. The region's complex intersection of ethnohistorical language groups could be a later consequence of the dispersal of swidden farming communities across a broader 


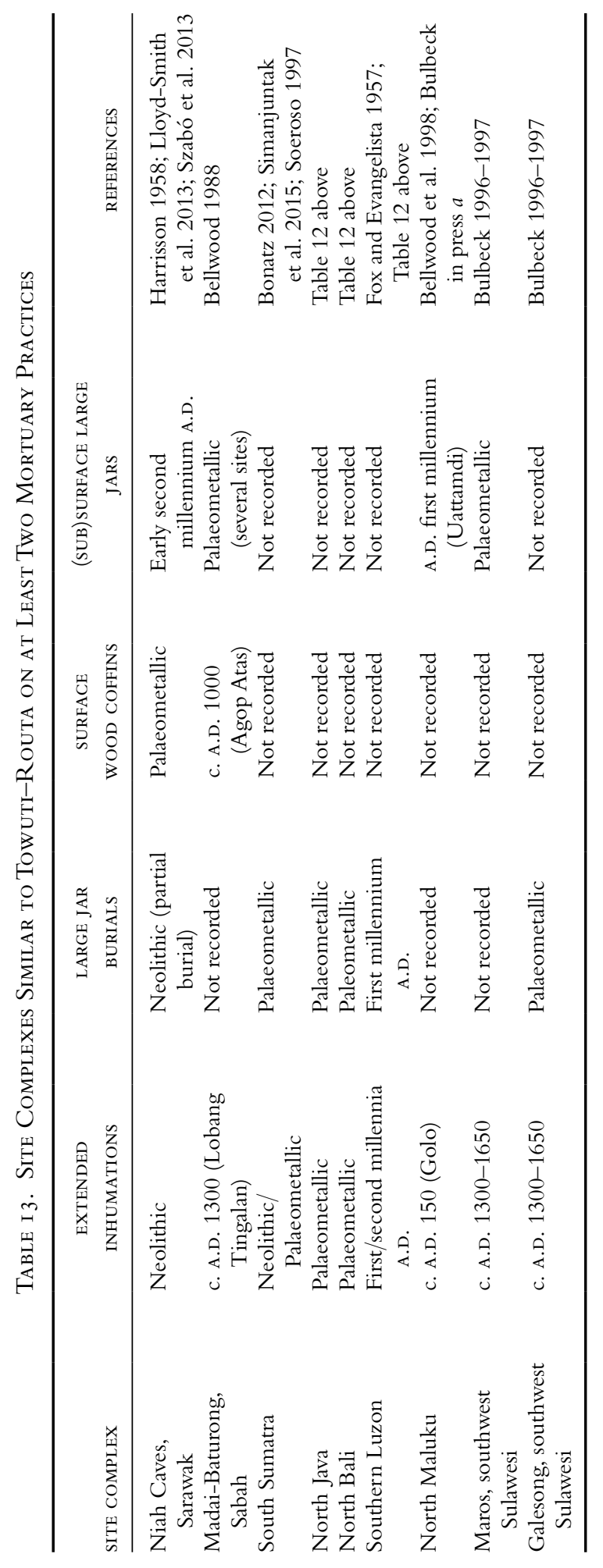


landscape that remained lightly inhabited through to the second millennium A.D., consistent with Mead's (1999) general reconstruction of Bungku-Mori linguistic relationships.

Of the Towuti-Routa burials that preceded the ethnohistorical mortuary disposals, the burial of the elderly female at Gua Talimbue is both the earliest and the richest. The disparity between her burial and that of the Gua Lampetia adolescent (no grave goods) could reflect a number of factors including differential status based on age, achievement, or birth. However, the modest nature of the ornaments (a shell ring and a bone pendant) recovered from the Gua Lampetia mortuary jar suggests at least a lack of any increased importation of exotic valuables into Towuti-Routa during the Palaeometallic period. Nonetheless, the jar's thick dammar coat testifies to the intensive local use of dammar by A.D. 1000. It is argued here that such large burial jars reflect an introduced mortuary practice. Further, Old Luwu (the plausible source of the practice) evidently experienced an increase in the availability of glass beads and other exotic valuables during the first millennium and into the early second millennium A.D. This supposition is founded on evidence for increased exploitation of its high-quality iron ore for smelting and implement production (Bulbeck and Caldwell 2000; Do 2013). Whilst acknowledging the merely exploratory nature of our available coverage of Towuti-Routa Palaeometallic archaeology, the evidence as it stands speaks against the role of dammar as a notable trade item prior to the ethnohistorical period.

By default, dammar is the most likely item exported in exchange for the considerable variety and volume of exotic goods, including high-fired ceramics and copper-based jewelry as well as cloth (reported ethnographically) and beads, associated with the Towuti-Routa ethnohistorical mortuary tradition. Although trade statistics point to a late nineteenth-century florescence of the Sulawesi dammar trade (Bulbeck 1993), the dammar trade in Old Luwu can be dated to between the seventeenth and twentieth centuries (Bulbeck and Caldwell 2000), similar to the inferred Towuti-Routa chronology. Further, the ready availability of dammar in the forests surrounding Lake Towuti and the valuable nature of its trade (Grubauer 1913) is echoed by the traditional role of dammar as the most valuable export from the highlands overlooking Sabbang Loang (Caldwell 2014).

The widespread distribution of the ethnohistorical mortuary tradition within Towuti-Routa suggests that the dispersed communities retained or regained their ancestral social connections as the dammar trade became increasingly attractive. The importation of exotic valuables would have provided an opportunity for social aggrandizers to control the ownership of these goods, leading to the development of a ranked society with well-to-do aristocrats and humble commoners (Bougas 2007). The congregation of the Towuti-Routa deceased in communal mortuary caves regardless of age or birth status suggests a belief system that prioritized the unity of the ancestors, different from the sharp social stratifications observable amongst more populous groups such as the Bugis and Makassarese of southwest Sulawesi (Bulbeck 1993, 1996-1997). Archaeological evidence for status differentiation within the TowutiRouta mortuary assemblages is hard to pin down, due to their intermingled status, apart from broad indications such as the distinction at Gua Andomo between its imported and locally produced jars of large size. However, archaeological survey near Routa of a fortress and a large artisans' settlement stand as confirmation for the development of a secure, ordered society by the late second millennium A.D. 
The overall perspective to be gathered from Towuti-Routa implicates the continued practice of ancestor worship associated with enhanced status differentiation, burgeoning trade, and the establishment of large settlements during the ethnohistorical period. The perspectives developed by Junker (2001) and Bacus (2004) for the Philippines, and Bulbeck (1996-1997) and Bougas (2007) for southwest Sulawesi, would view these last three phenomena as elements of political centralization, leading to chiefdoms that wielded authority over ranked societies at or within their boundaries.

To be sure, Bellwood (1996) has proposed that hierarchy lay at the heart of the Malayo-Polynesian linguistic expansion, at which time ambitious individuals migrated by land and sea to found communities to aggrandize their status and the status of their descendants. Bellwood noted the general division in Melanesia between MalayoPolynesian societies where status was inherited, and non-Austronesian societies where status was achieved, even though ancestor worship was virtually universal across Melanesia (Kiste 1994). However, as Bellwood conceded, the linguistic and archaeological evidence for any form of early Malayo-Polynesian ranking is weaker in ISEA than in the Pacific, although some sort of latent tendency-perhaps related to the social skills needed to mount successful sea-going expeditions-would have been at play. Accordingly, there may not be a necessary contradiction between historical linguistic approaches, with their implication of a tendency for early Malayo-Polynesian status differentiation, and evolutionary approaches that seek out the factors that crystallized these tendencies into a chiefly society, as appears to have transpired at TowutiRouta on the back of the dammar trade.

\section{ACKNOWLEDGMENTS}

"The Archaeology of Sulawesi: A Strategic Island for Understanding Modern Human Colonization and Interactions Across our Region" project was funded by the Australian Research Council (DP110101357). The Indonesian government's permission for the research was granted by the Bureau of Research and Technology (Visa 278/SIP/FRP/ SM/VII/2013). The fieldwork and laboratory work were facilitated by Bambang Sulistyanto (then Director) and Bagyo Prasetyo (Head of the Department of Prehistory) at the National Research Center of Archaeology in Jakarta, and by Made Sudarmika, then Director of the Makassar Archaeology Office. The authors thank Mai Lin Tjoa-Bonatz and an anonymous referee for their valuable comments.

\section{NOTES}

1. This project was funded by the Australian Research Council for a team of investigators including co-authors Sue O'Connor, Jack Fenner, and Ben Marwick, along with Janelle Stevenson of Australian National University. The funding was received by the Australian National University College of Asia and the Pacific in three tranches between 2012 and 2014, and included a small amount earmarked for laboratory work and publication of results in 2015 and 2016.

2. This project received major funding from the Australian Research Council during the years 19972000 as a grant to David Bulbeck (Australian National University) and Ian Caldwell (then at University of Hull). Supplementary funding was received by Ian Caldwell from the British Academy for South East Asian Studies in 2000 and by David Bulbeck from the Wenner-Gren Foundation for Anthropological Research in 1997, the Australia-Indonesia Institute in 1999, the Australian National University Centre for Archaeological Research in 1999 and 2000, the Australian Institute of Nuclear Science and Engineering in 2000, and the Australian National University Centre Faculties Research Grants Scheme in 2000.

3. For further discussion of the use of jars as mortuary containers, see overview recently prepared by Bulbeck (in press $b$ ). 


\section{REFERENCES CITED}

Adhyatman, Sumarah, and Redjeki Arifin

1996 Manik-Manik di Indonesia Beads in Indonesia, 2nd ed. Jakarta: Djambatan.

Anggraeni, Truman Simanjuntak, Peter Bellwood, and Philip Piper

2015 Neolithic foundations in the Karama valley, West Sulawesi, Indonesia. Antiquity 88:740-756.

Aplin, Ken, Sue O’Connor, Philip Piper, David Bulbeck, Ben Marwick, Emma St. Pierre, and FADHila AzIZ

2016 The Walandawe tradition from Southeast Sulawesi and osseous artifact traditions in Island Southeast Asia, in Osseous Projectile Weaponry: Towards an Understanding of Pleistocene Cultural Variability, ed. Michelle C. Langley. New York: Springer. DOI: 10.1007/978-94-024-0899-7.

Ardika, I. WAYAN

2000 Archaeological research at Bondalem, northeastern Bali. Bulletin of the Indo-Pacific Prehistory Association 19:81-83.

AzIz, Fadhila Arifin

2012 Archaeology-demography studies at Gilimanuk site (Bali), in Recent Studies in Indonesian Archaeology: 17-48, ed. Edi Sedyawati and I. Wayan Ardika. Delhi: B. R. Publishing Corporation.

Bacus, Elisabeth A.

2004 The archaeology of the Philippine Archipelago, in Southeast Asia from Prehistory to History: 257-281, ed. Ian Glover and Peter Bellwood. London: RoutledgeCurzon.

Bellwood, Peter

1988 Archaeological Research in South-Eastern Sabah. Monograph vol. 2, ed. Peter Bellwood. Kota Kinabalu: Sabah Museum.

1996 Hierarchy, founder ideology and Austronesian expansion, in Origins, Ancestry and Alliance: Explorations in Austronesian Ethnography: 18-40, ed. James J. Fox and Clifford Satther. Department of Anthropology, Research School of Pacific Studies. Canberra: Australian National University.

1997 Prehistory of the Indo-Malaysian Archipelago, rev. ed. Honolulu: University of Hawai‘i Press.

Bellwood, Peter, Goenadi Nitihaminoto, Geofrey Irwin, Gunadi, Agus Waluyo, and Daud TANUDIRJO

199835,000 years of prehistory in the northern Moluccas, in Bird's Head Approaches: Irian Jaya Studies - A Programme for Interdisciplinary Research: 233-275, ed. Gert-Jan Bartstra. Modern Quaternary Research in Southeast Asia 15. Rotterdam: A. A. Balkema.

BONATZ, DOMINIK

2012 A highland perspective on the archaeology and settlement history of Sumatra. Archipel $84: 35-81$.

BOUgas, WAyne

2007 Gold looted and excavated from late (1300 A.D.-1600 A.D.) pre-Islamic Makasar graves. Archipel 73:111-166.

Bronk Ramsey, Christopher

2013 Oxcal 4.2 manual. https://c14.arch.ox.ac.uk/oxcal/OxCal.html.

Bulbeck, DAvid

1993 New perspectives on early South Sulawesi history. Baruga 9:10-18. http://www.oxis.org/ theses/bulbeck-1992-summary.pdf.

1996- The Bronze-Iron Age of South Sulawesi, Indonesia: Mortuary traditions, metallurgy and 1997 trade, in Ancient Chinese and Southeast Asian Bronze Age Cultures, vol. II: 1007-1076, ed. F. David Bulbeck and Noel Barnard. Taipei: Southern Materials Center Inc.

2001 Island Southeast Asia Late Prehistoric: Indo-Malaysian Archipelago Early Metal Phase, Sa Huynh-Kalanay, in Encyclopedia of Prehistory, vol. 3: East Asia and Oceania: 82-116, ed. Peter N. Peregrine and Melvin Ember. New York: Kluwer Academic/Plenum Publishers.

2008 An archaeological perspective on the diversification of the languages of the South Sulawesi stock, in Austronesian in Sulawesi: 185-212, ed. Truman Simanjuntak. Jakarta: Center for Prehistoric and Austronesian Studies.

2009 The application of Darwinian cultural evolutionary theory to ceramics: The case of "soft pottery" from Luwu, South Sulawesi, Indonesia, in Theoretical and Methodological Issues in Evolutionary Archaeology - Toward an Unified Darwinian Paradigm: 3-11, ed. H. J. Muscio and G.E.J. López. BAR International Series 1915. Oxford: Hadrian Books. 
2011 Biological and cultural evolution in the population and culture history of Malaya's anatomically modern inhabitants, in Dynamics of Human Diversity: The Case of Mainland Southeast Asia: 207-255, ed. N. J. Enfield. School of Culture, History and Language, Pacific Linguistics 627. Canberra: Australian National University.

2014 The chronometric Holocene archaeological record of the southern Thai-Malay Peninsula. International Journal of Asia Pacific Studies 10(1): 112-162.

in press $a$ Bioarchaeological analysis of the Northern Moluccan excavated human remains, in Archaeology in the Northern Moluccas, Indonesia, ed. Peter Bellwood. Canberra: ANU E-Press.

in press $b$ Traditions of jars as mortuary containers in the Indo-Malaysian Archipelago, in New Perspectives in Southeast Asian and Pacific Prehistory, ed. Philip Piper, Hirofumi Matsumura, and David Bulbeck. Canberra: ANU E-Press.

Bulbeck, David, Doreen Bowdeery, John Field, and Bagyo Prasetyo

2007 The palace centre of sago city: Utti Batue site, Luwu, South Sulawesi, Indonesia, in Wetland Archaeology and Environments-Regional Issues, Global Perspectives: 119-140, ed. M. Lillie and S. Ellis. Oxford: Oxbow Books.

Bulbeck, David, and Ian Caldwell

2000 Land of Iron: The Historical Archaeology of Luwu and the Cenrana Valley. Hull: University of Hull Centre for South-East Asian Studies.

Bulbeck, David, Ambra Calo, Budianto Hakim, Hasanuddin, Moh. Husni, and Bagyo Prasetyo

2011 Archaeological report on Luwu Timur Kabupaten, South Sulawesi and Konawe Kabupaten, Southeast Sulawesi. Unpublished report. Canberra: Australian National University.

Caldwell, IAN

2014 Through the highlands of South Sulawesi. Review of Indonesian and Malaysian Affairs 48:5575.

Do, MisOL

2013 Iron-Nickel Alloy Smelting Production in Luwu, South Sulawesi during the Pre-Islamic Period. M.Sc. diss. in the Technology and Analysis of Archaeological Materials. University College, London. http://www.oxis.org/theses/misol-2103.pdf.

FAge, LuC-Henri

2014 Rapport préliminaire: Propection archéologique Massif de Matarombeo, Sulawesi Central, Octobre 2014 [Preliminary report: Archaeological prospecting in the Matarombeo Massif, Central Sulawesi, October 2014]. Le Kalimanthrope. http://kalimanthrope.com/sulawesi2014/ RAPPORT\%20SULAWESI-2014-OK.pdf.

Fox, Robert, and Alfredo Evangelista

1957 The Bato Caves, Sorsogon Province, Philippines: A preliminary report of a jar-burial-stone tool assemblage. Journal of East Asiatic Studies 6(1): 49-56.

Francis, Peter JR.

1999 Beads of the World, 2nd ed. Atglen, PA: Schiffer.

Friberg, Timothy, and Thomas V. Laskowske

1989 South Sulawesi languages, in Studies in Sulawesi Languages: 1-18, ed. James N. Sneddon. Jakarta: Badan Penyelenggara Seri Nusa.

Glover, IAN C.

1965 Ulu Leang cave, Maros: A preliminary sequence of post-Pleistocene cultural development in South Sulawesi. Archipel 11:113-154.

Grubauer, Albert

1913 Unter Kopfjägern in Central-Celebes: Ethnologische Streifzüge in Sudost- und Central-Celebes [Amongst headhunters in Central Celebes: Ethnological expeditions in Southeast and Central Celebes]. Leipzig: R. Voigtlander.

Harrisson, Barbara

1958 Niah's Lobang Tulang (“Cave of Bones”). Sarawak Museum Journal 8:569-619.

1990 Pusaka: Heirloom Jars of Borneo. Singapore: Oxford University Press.

Henson, Florante G.

1992 Jar burial excavations in the Philippines, in Early Metallurgy, Trade and Urban Centres in Thailand and Southeast Asia: 213-225, ed. Ian Glover, Pornchai Suchitta, and John Villiers. Bangkok: White Lotus.

HiLlson, SimON

1996 Dental Anthropology. Cambridge: Cambridge University Press. 
JUNKER, LAURA

2001 The evolution of ritual feasting systems in prehispanic Philippine chiefdoms, in Feasts: Archaeological and Ethnographic Perspectives on Food, Politics and Power: 267-310, ed. Michael Dietler and Brian Hayden. Washington, D.C.: Smithsonian Institution Press.

Kiste, Robert C.

1994 Pre-colonial times, in Tides of History: The Pacific Islands in the Twentieth Century: 3-28, ed. K. R. Howe, Robert C. Kiste, and Brij V. Lal. Honolulu: University of Hawai'i Press.

Kress, JONATHON H.

2004 The necrology of Sa'gung rockshelter and its place in Philippine prehistory, in Southeast Asian Archaeology: Wilhelm G. Solheim II Festschrift: 239-275, ed. Victor Paz. Quezon City: The University of the Philippines Press.

LIONG, LiE GOAN

1965 Palaeoanthropological results of the excavation at the coast of Lewoleba (Isle of Lomblen). Anthropos 60:609-624.

Lloyd-Smith, Lindsay, Graeme Barker, Huw Barton, Judith Cameron, Faye Cole, Patrick Daly, Chris Doherty, Chris Hunt, John Krigbaum, Helen Lewis, Jessica Manser, Victor Paz, Philip J. Piper, Ryan J. Rabett, Garry Rushworth, and Katherine Szabó

2013 "Neolithic" societies c. 4000-2000 years ago: Austronesian farmers?, in Rainforest Foraging and Farming in Island Southeast Asia: The Archaeology of the Niah Caves, Sarawak, vol. 1:255-298, ed. Graeme Barker. Cambridge: McDonald Institute for Archaeological Research.

Manguin, Pierre-Yves, and Agustijanto Indradjaja

2011 The Batujaya site: New evidence of early Indian influence in West Java, in Early Interactions between South and Southeast Asia: 113-136, ed. Pierre-Yves Manguin, A. Mani, and Geoff Wade. Singapore: Institute of Southeast Asian Studies.

McWilliam, Andrew, and Stephan Lorenzen

2009 Sulawesi Nickel Baseline and Community Relations Project. Unpublished report. Canberra: Australian National University.

MeAd, David E.

1999 The Bungku-Tolaki Languages of South-Eastern Sulawesi, Indonesia. Pacific Linguistics Series D, vol. 91. Canberra: Australian National University.

NoERwidi, Sofwan

in press Evidence from dental metrical analysis on the Holocene population history of Java, in New Perspectives in Southeast Asian and Pacific Prehistory, ed. Philip Piper, Hirofumi Matsumura, and David Bulbeck. Canberra: ANU E-Press.

O’Connor, Sue, fadhila Arifin Aziz, Ben Marwick, Jack Fenner, Bagyo Prasetyo, David Bulbeck, Tim Maloney, Emma St. Pierre, Rose Whitau, Unggul Prasetyo Wibowo, Budianto Hakim, Ambra Calo, fakhri, Moh. Husni, Hasanuddin, Adhi Agus Oktaviana, Dyah Prastinintyas, Fredeliza Z. Campos, and Philip J. Piper

2014 Final report on the project "The Archaeology of Sulawesi: A Strategic Island for Understanding Modern Human Colonization and Interactions Across our Region." Unpublished report. Canberra: The Australian National University.

Oxenham, Marc, and Hallie R. Buckley

2015 The population history of Mainland and Island Southeast Asia, in The Routledge Handbook of Bioarchaeology in Southeast Asia and the Pacific Islands: 36-54, ed. Marc Oxenham and Hallie Buckley. London: Taylor and Francis.

Reimer, Paula J., Edouard Bard, Alex Bayliss, J. Warren Beck, Paul G. Blackwell, Christopher Bronk Ramsey, Caitlin E. Buck, Hai Cheng, R. Lawrence Edwards, Michael Friedrich, Pieter M. Grootes, Thomas P. Guilderson, Haflidi Haflidason, Irka Hadjas, Christine Hatté, Timothy J. Heaton, Dirk L. Hoffman, Alan G. Hogg, Konrad A. Hughen, K. Felix Keiser, Bernd Kromer, Stuart W. Manning, Mu Niu, Ron W. Reimer, David A. Richards, E. Marian Scott, John R. Southon, Richard A. Staff, Christian S. M. Turney, and Johannes van der Plicht

2013 IntCal 13 and Marine13 radiocarbon age calibration curves 0-50,000 years cal B.P. Radiocarbon 55(4) : 1869-1887.

Simanjuntak, Truman, François SÉmah, and Anne-Marie SÉmah

2015 Tracking evidence for modern human behavior in Paleolithic Indonesia, in Emergence and Diversity of Human Behavior in Paleolithic Asia: 158-170, ed. Yousuke Kaifu, Masami Izuho, Ted Goebel, Hiroyuki Sato, and Akira Ono. College Station: Texas A\&M University Press. 
Simanjuntak, Truman, and Joko Siswanto

2008 The Neolithic of northern Sulawesi, in Austronesian in Sulawesi: 129-141, ed. Truman Simanjuntak. Jakarta: Center for Prehistoric and Austronesian Studies.

Soejono, R. P.

2008 Sistem-Sistem Penguburan pada Akhir Masa Prasejarah di Bali. Jakarta: Pusat Penelitian dan Pengambangan Arkeologi Nasional.

SOEROSO

1997 Recent discoveries of jar burials in South Sumatra. Bulletin de l'Ecole française d'Extrême-Orient $84: 418-422$.

Solheim, Wilhelm G. II

1960 Jar burial in the Babuyan and Batanese Islands and in Central Philippines, and its relationship to jar burial elsewhere in the Far East. Philippine Journal of Science 8-9:115-148.

1964 Pottery and the Malayo-Polynesians: Archaeological evidence. Current Anthropology 5:376384.

SukAdana, A. Adi

1981 Peninggalan manusia di Liang Bua dan hubungannya dengan penemuan di Lewoleba dan Melolo. Berkala Bioantropologi Indonesia 1:53-72.

Szabó, Katherine, Faye Cole, Lindsay Lloyd-Smith, Graeme Barker, Chris Hunt, Philip J. Piper, AND Chris DOHERTY

2013 The "Metal Age" at the Niah Caves, c. 2000-500 years ago, in Rainforest Foraging and Farming in Island Southeast Asia: The Archaeology of the Niah Caves, Sarawak, vol. 1:299-340, ed. Graeme Barker. Cambridge: McDonald Institute for Archaeological Research.

Szabó, Katherine, Mary Clare Swete Kelly, and Antonio Peñalosa

2004 Preliminary results from excavations in the eastern mouth of Ille Cave, northern Palawan, in Southeast Asian Archaeology: Wilhelm G. Solheim II Festschrift: 209-224, ed. Victor Paz. Quezon City: The University of the Philippines Press.

Tenazas, Rosa C. P.

1968 A Report on the Archaeology of the Locsin-University of San Carlos Excavations in Pila, Laguna, September 4, 1967 to March 19, 1968. Manila.

Tillotson, Dianne

1989 Mortuary patterning and the evolution of the rice ancestors. Bulletin of the Indo-Pacific Prehistory Association 9:1-14.

Valentin, Frédérique, Jeong-in Choi, Hsiuman Lin, Stuart Bedford, and Matthew Spriggs

2015 Three-thousand-year-old jar burials at the Teouma cemetery (Vanuatu): A Southeast AsianLapita connection?, in The Lapita Cultural Complex in Time and Space: Expansion Routes, Chronologies and Typologies: 81-101, ed. Christophe Sand, Scarlett Chiu, and Nicholas Hogg. Noumea: Institut d'archéologie de la Nouvelle-Calédonie et du Pacifique.

VAN DER Plas, M.

2007 A new model for the evolution of Homo sapiens from the Wallacean islands. Palarch 1(1). http://www.palarch.nl/wp-content/plas_van_der_m_a_new_model_for_the_evolution_of_ homo_sapiens_from_the_wallacean_islands_palarchs_journal_of_vertebrate_palaeontology_ 1_1_20071.pdf.

van HeEkeren, H. R.

1956 Note on a proto-historic urn-burial site at Anjar, Java. Anthropos 51:194-201.

1958 The Bronze-Iron Age of Indonesia. The Hague: Martinus Nijhoff.

VAN KLINKen, Gert J.

1999 Bone quality indicators for paleodietary and radiocarbon measurements. Journal of Archaeological Science 26(6) : 687-695.

\section{ABSTRACT}

Archaeological evidence from survey and cave excavation in the Towuti-Routa region of Sulawesi suggests the following sequence of late Holocene cultural change. Settled communities whose subsistence included an agricultural component had established themselves by the early centuries A.D. and began the use of caves for mortuary purposes. Extended inhumations are the oldest attested mortuary practice, overlapping in time 
with secondary burials in large earthenware jars dated to around A.D. 1000. The third, ethnohistorically described practice involved the surface disposal of the deceased, including the use of imported martavans for the elite, between approximately A.D. 1500 and 1900. This sequence of mortuary practices has not been documented elsewhere in Island Southeast Asia, although each practice has multiple parallels. The Towuti-Routa dammar trade, which was at its peak at the time of European contact, can perhaps account for the quantity of exotic items imported to the region but not the specifics of the mortuary practices. KeYwords: Sulawesi archaeology, Island Southeast Asia mortuary practices, Sulawesi dammar trade, Southeast Sulawesi. 